\title{
ANAYASA MAHKEMESİ BİREYSEL BAŞVURU KARARLARINDA DEVLET MEMURLARININ IIFADE ÖZGÜRLÜĞÜ: HASAN GÜNGÖR, HASAN GÜNGÖR (2) VE ZEKİ ÇINAR BAŞVURULARI
}

FREEDOM OF EXPRESSION OF CIVIL SERVANTS IN THE CONSTITUTIONAL COURT INDIVIDUAL APPLICATION DECISIONS: HASAN GÜNGÖR, HASAN GÜNGÖR (2) AND ZEKI

\section{IÇiNDEKILER}

GİRIS 557

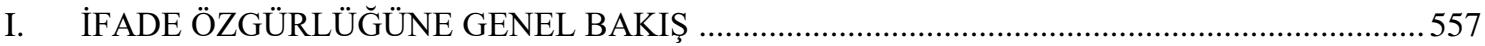

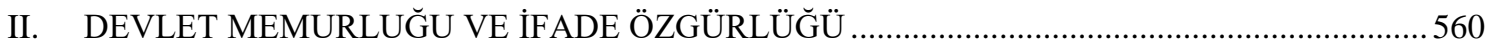

III. ANAYASA MAHKEMESI BİREYSEL BAŞVURU KARARLARININ INCELENMESİ VE

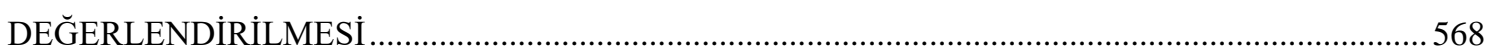

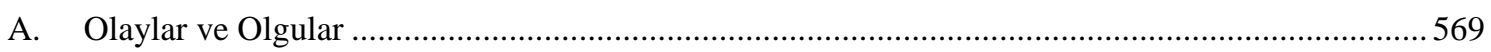

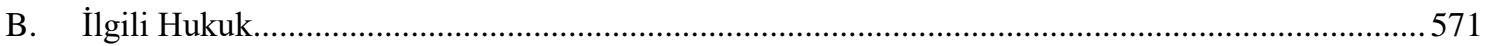

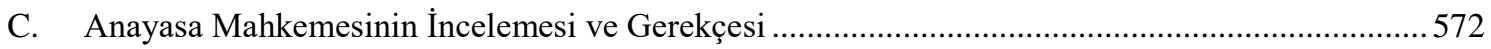

1. Kanunilik ve Meşru Amaç Değerlendirmesi ...................................................................................... 573

2. Demokratik Toplum Düzeninin Gereklerine Uygunluk Değerlendirmesi .........................................576

IV. ANAYASA MAHKEMESİ KARARLARI IŞIĞINDA DEVLET MEMURLARININ İFADE

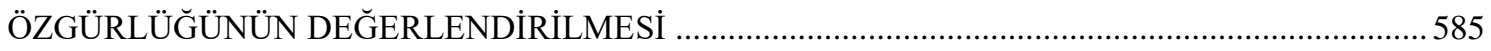

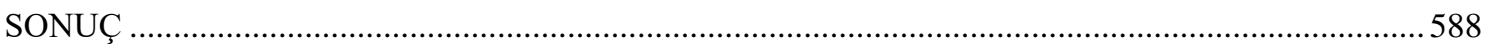

DOI: $10.32957 /$ hacettepehdf. 797090

Makalenin Geliş Tarihi: 18.09.2020 Makalenin Kabul Tarihi: 03.03.2021

* Araştırma Görevlisi, Koç Üniversitesi Hukuk Fakültesi İdare Hukuku Anabilim Dalı.

E-posta: akula@ku.edu.tr

ORCID: 0000-0001-8305-9216

Bu makalenin Hacettepe Üniversitesi Hukuk Fakültesi Dergisi Araştırma ve Yayın Etiği İlkelerine uygun olarak hazırlandığını beyan ederim. 


\title{
ÖZ
}

İfade özgürlüğünün korunması demokrasinin en temel gereklerinden biridir; fakat devlet memurluğu statüsü memurların tarafsızlık yükümlülüğü çerçevesinde bu özgürlüğün sınırlanmasına sebep olabilmektedir. T.C. Anayasa Mahkemesi, Hasan Güngör, Hasan Güngör (2) ve Zeki Çınar bireysel başvuru kararlarında, devlet memurlarının ifade özgürlüklerini detaylı olarak ele almakta ve ifade özgürlüklerinin ihlal edildiğine karar vermektedir. $\mathrm{Bu}$ çalışma ile bu kararların incelenmesi ve bu doğrultuda devlet memurlarının ifade özgürlüğünün değerlendirilmesi hedeflenmektedir.

Anahtar kelimeler: bireysel başvuru, devlet memuru, ifade özgürlüğü, Hasan Güngör, Zeki Çınar

\begin{abstract}
Protection of the freedom of expression is one of the main requirements of the democracy; however, the civil service status may cause limitation of the freedom of expression within the framework of the impartiality of the civil servants. The Turkish Constitutional Court analyzed the freedom of expression of civil servants in its individual application decisions Hasan Güngör, Hasan Güngör (2) and Zeki Çınar, and decided that the freedom of expression was violated. This paper aims to evaluate these decisions and assess the freedom of expression of civil servants with that regard.
\end{abstract}

Key words: individual application, civil servant, freedom of expression, Hasan Güngör, Zeki Çınar 


\section{GíRiș}

T.C. Anayasa Mahkemesinin (“AYM”) ifade özgürlügüne ilişkin değerlendirmede bulunduğu bireysel başvuru kararları incelendiğinde, AYM'nin Hasan Güngör, Hasan Güngör (2) ve Zeki Çınar kararlarında, ${ }^{1}$ devlet memurlarının ifade özgürlüklerini detaylı olarak ele aldığı görülmektedir. Bu çalışma ile söz konusu kararların incelenmesi ve kararlar çerçevesinde devlet memurlarının siyasi ifade özgürlüğünün ele alınması hedeflenmektedir. $\mathrm{Bu}$ çalışmada devlet memurluğu statüsünü haiz kişilerin ifade özgürlükleri özellikle tarafsızlık yükümlülüğü çerçevesinde incelenecektir. Bununla birlikte, devlet memurluğu statüsüne giriş bakımından ifade özgürlüğü ve devlet memurlarının siyasi hakları olarak değerlendirilebilecek siyasi partiye üye olma hakkı, sendika kurma hakkı, grev hakkı, toplantı ve gösteri yürüyüşü düzenleme hakkı gibi hakları çalışma kapsamı dışında tutulmaktadır. Bu çalışma, ifade özgürlüğü, devlet memurluğu ve ifade özgürlüğü, Anayasa Mahkemesi bireysel başvuru kararlarının incelenmesi ve değerlendirilmesi ve Anayasa Mahkemesi kararları 1şı̆̆ında devlet memurlarının ifade özgürlüğünün değerlendirilmesi olmak üzere dört ana bölümden oluşmaktadır.

\section{I. İFADE ÖZGÜRLÜĞÜNE GENEL BAKIŞ}

İnsanın en değerli haklarından biri olarak nitelendirilen ifade özgürlüğü ${ }^{2}$ temel olarak “düşünce, fikir, bilgi ve kanaatlerin dışavurum serbestliğgi” olarak tanımlanabilir ${ }^{3}$. “Demokratik rejimlerin kurucu öğesi” olan ifade özgürlüğünün sağlanması çoğulculuğun

1 Hasan Güngör, Başvuru No: 2013/6152, 24.02.2016; Hasan Güngör (2), Başvuru No: 2915/1554, 25.12.2018; Zeki Çınar Başvuru No: 2016/3585, 12.06.2019.

2 TEZIÇ, Erdoğan, “Türkiye'de Siyasal Düşünce ve Örgütlenme Özgürlüğü”, Anayasa Yargısı Dergisi, Y1l: 1990, Cilt: 7, (s. 31-46), s. 32.

3 KABOĞLU, İbrahim, "Düşünce Özgürlüğü”, İnsan Hakları, (der. K. Tankuter), Yapı Kredi Yayınları, İstanbul, 2000, (s. 106-120), s. 109. İfade özgürlüğüne ilişsin kullanılan terminolojilere iliş̧in bkz. SUNAY, Reyhan, Avrupa Sözleşmesinde ve Türk Anayasasında İfade Hürriyetini Muhtevası ve Sinırları, Liberal Düşünce Topluluğu, Ankara, 2001, s. 5-6. 
ön koşuludur ${ }^{4}$. İfade özgürlüğü, gerçeğin araştırılıp ortaya çıkarılmasında ${ }^{5}$ ve bireyin ve toplumun gelişmesinde ve ilerlemesinde önemli bir rol oynamaktadır ${ }^{6}$. Bu özgürlüğün engellenmesiyle birlikte kişinin onurlu bir hayat sürdürme hakkı ve maddi ve manevi varlığını geliştirme hakkının elinden alınmış olacağ ${ }^{7}$ belirtildiği gibi, ifade özgürlüğünün “eksen” özelliğini haiz olarak diğer temel hak ve özgürlükler için "besleyici” bir kaynak teşkil ettiği de ifade edilmektedir ${ }^{8}$. İfade özgürlüğü "düşünceyi açıklama ve yayma hürriyeti” madde başlığı altında T.C. Anayasası (“Anayasa”) md. 26 ve "ifade özgürlüğü” (freedom of expression) madde başlığı ile İnsan Hakları Avrupa Sözleşmesi (“IHHAS”) Md. 10 ile güvence altına alınmaktadır. Anayasa md. 26/1 uyarınca "herkes, düşünce ve kanaatlerini söz, yazı, resim veya başka yollarla tek başına veya toplu olarak açıklama ve yayma hakkına sahiptir." İHAS md. 10/1 uyarınca da "herkes ifade özgürlüğü hakkına sahiptir. $\mathrm{Bu}$ hak, kamu makamlarının müdahalesi olmaksızın ve ülke sınırları gözetilmeksizin, kanaat özgürlüğünü ve haber ve görüş alma ve de verme özgürlügünü de kapsar."

Düşünce özgürlüğünün anlamlı olabilmesi için ifade özgürlüğünün düşünce özgürlüğü kadar geniş olması gerektiği de belirtilmiş olmak ile birlikte, ${ }^{9}$ ifade özgürlüğü Anayasada sınırlanabilir bir hak olarak düzenlenmektedir ${ }^{10}$. Anayasa md. 26/2 uyarınca

4 KABOĞLU, 2000, s. 107. KABOĞLU, düşünce özgürlüğ̈̈nü değerlendirmekte ve ifade özgürlüğünü düşünce özgürlüğü kapsamında ele almaktadır. Bkz. a.g.e. s. 106.

5 UYGUN, Oktay, “Avrupa İnsan Hakları Sözleşmesi ve Türk Hukukunda İfade Özgürlügünün Sınırlanması”, Türkiye'de İfade Özgürlüğü, (der. T. Koçak, vd.), BGST Yayınları, İstanbul, 2009, (s. 15-67), s. 17.

6 SELÇUK, Sami, "Düşün Özgürlüğü,, Düşünce Özgürlüğ̈̈, (Hazırlayan: H. Ökçesiz), Afa Yayınları, İstanbul, 1998, (s. 293-314), s. 305-307; TEZCAN, Durmuş / ERDEM, Mustafa Ruhan / SANCAKDAR, Oğuz, vd., İnsan Hakları El Kitabı, Güncellenmiş 7. Basım, Seçkin Yayıncılık, Ankara, Eylül 2018, s. 448.

7 SUNAY, 2001, s. 9.

8 KABOĞLU, 2000, s. 107; KABOĞLU, İbrahim, Özgürlükler Hukuku, Afa Yayınları, İstanbul, 1993, s. 193. Ayrica bkz. SUNAY, 2001, s. 10.

9 TANÖR, aksi durumda düşünce özgürlüğünün "göz boyamadan başka bir şey” ifade etmeyeceğini belirtmektedir. TANÖR, Bülent, Siyasi Düşünce Hürriyeti ve 1961 Türk Anayasası, Öncü Kitapevi, İstanbul, 1969, s. 27. İfade özgürlüğünün sağlanamadığı durumda bireyin düşüncelerinin serbestçe oluştuğundan söz edilebilir olmayacağı da belirtilmektedir. Bkz. SUNAY, 2001, s. 6.

10 GÜRİZ, Adnan, “İfade Hürriyetinin Sınırları”, Düşünce Özgürlüğü, (Hazırlayan: H. Ökçesiz), Afa Yayınları, İstanbul, 1998, (s. 82-86), s. 82; KARAN, Ulaş, "İfade Özgürlüğü Hakkı", İnsan Hakları 
ifade özgürlüğünün kullanılması "millî güvenlik, kamu düzeni, kamu güvenliği, Cumhuriyetin temel nitelikleri ve Devletin ülkesi ve milleti ile bölünmez bütünlüğünün korunması, suçların önlenmesi, suçluların cezalandırılması, Devlet sırrı olarak usulünce belirtilmiş bilgilerin açıklanmaması, başkalarının şöhret veya haklarının, özel ve aile hayatlarının yahut kanunun öngördüğü meslek sırlarının korunması veya yargılama görevinin gereğine uygun olarak yerine getirilmesi” amaçlarıyla sınırlanabilir. İHAS md. 10/2 uyarınca ise ifade özgürlüğü "ulusal güvenliğin, toprak bütünlüğünün veya kamu güvenliğinin korunması, kamu düzeninin sağlanması ve suç işlenmesinin önlenmesi, sağlığın veya ahlakın, başkalarının şöhret ve haklarının korunması, gizli bilgilerin yayılmasının önlenmesi veya yargı erkinin yetki ve tarafsızlığının güvence altına alınması" amaçlarıyla sınırlanabilir. Bu noktada belirtmek gerekir ki, temel hak ve özgürlüğün sınırlandırılmasında hangi meşru amaca sahip olunursa olsun, özgürlükler istisnai olarak sınırlanabilir ${ }^{11}$. İfade özgürlüğünün sınırlanması için çok önemli bir meşru menfaatin bulunmas1 ${ }^{12}$ ve özgürlüğe getirilen sınırlamaların en asgari ve en zaruri sınırlamalar olması gerekmektedir ${ }^{13}$. Nitekim ifade özgürlüğünün sınırlandırılması da temel hak ve özgürlüklerin sınırlanması rejimine tabidir ${ }^{14}$. Anayasa md. 13 uyarınca "temel hak ve hürriyetler, özlerine dokunulmaksızın yalnızca Anayasanın ilgili maddelerinde belirtilen sebeplere bağlı olarak ve ancak kanunla sinırlanabilir. Bu sınırlamalar, Anayasanın sözüne ve ruhuna, demokratik toplum düzeninin ve lâik Cumhuriyetin gereklerine ve ölçülülük ilkesine aykırı olamaz”. İHAS md. 10/2 uyarınca ise ifade özgürlüğü, sınırlamanın yasayla öngörülmesi, belirtilen amaçlar için gerçekleştirilmesi ve demokratik toplumda gerekli olması şartıyla sınırlanabilir.

Avrupa Sözleşmesi ve Anayasa: Anayasa Mahkemesine Bireysel Başvuru Kapsamında Bir İnceleme, (der. S. İnceoğlu), 3. Bası, Beta, İstanbul Ekim 2013, (s. 355-379), s. 373.

11 AYM, E. 1985/8, K.1986/27, T. 26.11.1986. Ayrıca bkz. TANÖR, Bülent, "Temel Hak ve Özgürlüklerin Genel Rejimi”, İnsan Hakları, (der. K. Tankuter), Yapı Kredi Yayınları, İstanbul, 2000, (s. 47-56), s. 51; SUNAY, 2001, s. 74.

12 GÜRAN, Sait, İ́ade Hürriyeti Üzerine İdare’nin Yetkileri, İstanbul Üniversitesi Yayınları No: 1337 , Cezaevi Matbaası, İstanbul, 1969, s. 393. GÜRAN, 1961 Anayasası dönemini değerlendirmekle birlikte, aynı değerlendirmeler 1982 Anayasası için de yapılabilir.

13 GÜRAN, 1969, s. 350. İfade özgürlüğünün demokratik toplumdaki önemi için ayrıca bkz. a.g.e, s. 349.

14 KARAN, 2013, s. 373. 


\section{DEVLET MEMURLUĞU VE IFADE ÖZGÜRLÜĞÜ}

Devlet memurluğu statüsü, ${ }^{15}$ devlet memurlarının vatandaş kimliğinden ziyade devlet memurluğu kimliğinin esas alınması sebebiyle ifade özgürlüğünün sınırlanmasına sebep olabilmektedir ${ }^{16}$. Devlet memurlarına getirilen sınırlamalar göz önünde bulundurulduğunda Türk hukukunun devlet memurunu depolitize etmeyi amaçladığ $1^{17}$ ve siyasal yansızlık konusunda katı bir sistem uyguladığı belirtilmektedir ${ }^{18}$. İdarenin siyaset ile ilişkisini belirleyen ana kavramlardan biri olarak ele alınan yansızlık kavramı, ${ }^{19}$ devlet memurlarının DMK md. 7 ile öngörülen tarafsızlık yükümlülügü ile açıklanmaktadır. Bu madde doğrultusunda devlet memurları "hiçbir şekilde siyasi ve ideolojik amaçlı beyanda ve eylemde bulunamazlar ve bu eylemlere katılamazlar." DMK md. 125 uyarınca karşılığında uyarma cezası öngörülen "devlet memuru vakarına yakışmayan tutum ve davranışta bulunmak"; kınama cezası öngörülen "hizmet dışında Devlet memurunun itibar ve güven duygusunu sarsacak nitelikte davranışlarda bulunmak"; aylıktan kesme cezası öngörülen "hizmet içinde Devlet memurunun itibar ve güven duygusunu sarsacak nitelikte davranışta bulunmak"; kademe ilerlemesinin durdurulması cezası öngörülen "herhangi bir siyasi parti yararına veya zararına fiilen faaliyette bulunmak"; ve devlet memurluğundan çıkarma cezası öngörülen "yasaklanmış her türlü yayını veya siyasi veya ideolojik amaçlı bildiri, afiş, pankart, bant ve benzerlerini basmak, çoğaltmak, dağıtmak

15 Bu çalışma bakımından devlet memurları Anayasa Md. 128/1 ve 657 sayılı Devlet Memurları Kanunu ("DMK") md. 4/1/A uyarınca "Devlet ve diğer kamu tüzel kişiliklerince genel idare esaslarına göre yürütülen asli ve sürekli kamu hizmetlerini ifa ile görevlendirilen” kişiler olarak tanımlanabilir.

16 KAMAN KARAN, Nur, Devlet Memurluğunun Sona Ermesi, Seçkin Yayıncılık, Ankara, 2003, s. 118. Kaman Karan konuyu siyasal haklardan yararlanılmasına getirilen sınırlama olarak ele almaktadır. Ayrıca bkz. ÇİTÇİ, Oya, "Siyasal Haklar ve Kamu Görevlileri”, İnsan Hakları ve Kamu Görevlileri, (Yayına Hazırlayan: Mesut Gülmez), Türkiye ve Orta Doğu Amme İdaresi Enstitüsü, Ankara, 1992, (s. 89-110), s. 90-91.

17 KAMAN KARAN, 2003, s. 120.

18 GÜRAN, Sait, Memur Hukukunda Kayırma ve Liyakat Sistemi, Fakülteler Matbaası, İstanbul, 1980, s. 230. Güran “yansızlık” kavramını kullanmaktadır.

19 GÜVEN, H. Sami, "İdare Siyaset İlişkileri ve Personel Yönetimi Açısından Önemi”, Amme İdaresi Dergisi, Y1l: 1976, Cilt: 9, Say1: 1, (s. 50-70), s. 56. 
veya bunları kurumların herhangi bir yerine asmak veya teşhir etmek", "memurluk sıfatı ile bağdaşmayacak nitelik ve derecede yüz kızartıcı ve utanç verici hareketlerde bulunmak" ve "yurt dışında Devletin itibarını düşürecek veya görev haysiyetini zedeleyecek tutum ve davranışlarda bulunmak" fiilleri tarafsızlık yükümlülüğü ile ilişkilendirilebilir. Bu çalışma kapsamında, "herhangi bir siyasi parti yararına veya zararına fiilen faaliyette bulunmak" fiili inceleme konusu AYM kararları doğrultusunda önem arz etmektedir.

Tarafsızlık yükümlülügüünün temelinde iki unsura dayandığı görülmektedir. İlki, siyasilerin belirli bir görüşü uygulama doğrultusunda devlet memurlarını kendi çıkarlarına göre hareket etmeye zorlama eğilimleri karşısında devlet memurlarının üzerinde baskı yapılmasının engellenmesidir ${ }^{20}$. İkincisi ise kendi kişisel, siyasi veya ideolojik anlayışlarına ya da menfaatlerine göre hareket etme eğilimi karşısında devlet memurlarının görevlerine siyasi fikirlerini karıştırmaması, ${ }^{21}$ kamu gücünün siyasi parti yararına kullanılmaması, ${ }^{22}$ kamu hizmetinin nesnel olması, ${ }^{23}$ diğer bir ifadeyle devlet memurunun görevini yerine getirirken tüm vatandaşlara eşit ve objektif davranmasıdır ${ }^{24}$. Liyakat sisteminin de ilkeleri olarak değerlendirilen bu unsurların ${ }^{25}$ amacının temel olarak hem devlet memurunu hem de hizmet alanları korumak olduğu görülmektedir.

$\mathrm{Bu}$ unsurlar değerlendirildiğinde tarafsızlık yükümlülüğünün arkasında devlet memurlarının ve vatandaşların temel hak ve özgürlüklerinin korunmasının bulunduğu

20 KAMAN KARAN, 2003, s. 121; GÜRAN, 1980, s. 152. Benzer şekilde bkz. SANCAKDAR, Oğuz, Disiplin Yaptırımı Olarak Devlet Memuriyetinden Çıkarma ve Yargısal Denetim, Yetkin Yayınları, Ankara, 2001, s. 203.

21 KAMAN KARAN, 2003, s. 121. GÜRAN, 1980, s. 152.

22 ONAR, Sıddık Sami, İdare Hukukunun Umumi Esasları, Cilt: 2, 3. Basım, İsmail Akgün Matbaası, İstanbul, 1966, s. 1177. Onar, siyasi faaliyetlerde bulunmamak borcuna ilişkin olarak bu değerlendirmeyi yapmaktadır.

23 ERSÖZ, A. Kürşat, "Devlet Memurlarının Siyaset Yapma Yasağı ve Değerlendirilmesi”, Türkiye Adalet Akademisi Dergisi, Y1l: Nisan 2016, Say1: 26, (s. 71-104), s. 90.

24 SANCAKDAR, 2001, s. 201. Benzer şekilde bkz. GÜVEN, 1976, s. 57.

25 GÜRAN, 1980, s. 152. Liyakatli personelin kamu hizmetinin yürütülmesinde zorunlu olduğuna ve liyakata dayalı bir kamu hizmeti yürütülmesinin “ana davası”nın personel yönetimi olduğuna ilişkin bkz. GİRITLİ, İsmet, "Devlet Memurları Kanunu Tasarısı ve Bazı Eksiklikleri”, İstanbul Üniversitesi Hukuk Fakültesi Mecmuası, Cilt: 30, Sayı: 1-2, (s. 3-12), s. 4. 
tespiti yapılabilir. Devlet memurlarına sınırlama getirilmesi, iktidarın devlet memurunu görüşünü açıklamaya zorlayamaması anlamına gelmektedir. Bu şekilde aslında tarafsızlık yükümlülüğü ile birlikte, kadrolaşma tehlikesi de göz önünde bulundurulduğunda, ${ }^{26}$ devlet memurlarının Anayasa md. 25 ile güvence altına alınan düşünce ve kanaatlerini açıklamama hakkının korunduğu ifade edilebilir. İkinci unsur ile hedeflenen ise bireylerin düşüncelerine göre bir ayrım yapılmaması, ${ }^{27}$ diğer bir ifade ile devlet memurlarının taraflı davranarak veya taraflı olduklarına dair bir izlenim yaratarak vatandaşların kamu hizmetine erişimlerinin engellenmesinin önüne geçilmesi ve sunulan hizmet ile amaçlanan ihtiyaçların sağlanmasıdır ${ }^{28}$. Bu amaç ile birlikte vatandaşların temel hak ve özgürlüklerinin de güvence altına alındığı görülmektedir. Devlet memurlarının taraflı davranarak bireylerin temel hak ve özgürlüklerinin sağlanmasının önüne geçilmesiyle vatandaşların temel hak ve özgürlüklerinin korunması sağlanacaktır. Bir doktorun siyasi görüşü sebebiyle bir hastasına gerektiği özeni göstermeyerek bireylerin sağlık hizmetinden faydalanmasının engellenmesinin önüne geçilerek vatandaşların Anayasa md. 56 ile güvence altına alınan sağlıklı ve dengeli bir çevrede yaşama hakkının sağlanması bu duruma örnek verilebilir.

$\mathrm{Bu}$ sebeplerle, tarafsızlık yükümlülüğü gerek devlet memurunun gerekse vatandaşların haklarının korunması adına önem teşkil etmektedir ve tarafsızlığın zedelenmesi demokratik toplum için tehlike arz etmektedir ${ }^{29}$. Fakat, demokratik toplumlarda tüm vatandaşlar ülke sorunlarına yönelik fikir belirtebilmelidir ${ }^{30}$. Bu doğrultuda, tarafsızlık yükümlülüğünün devlet memurunun hiçbir fikre sahip olmaması veya bu yönde bir faaliyette bulunmaması anlamı taşımaması gerekmektedir ${ }^{31}$. Belirtmek

26 SANCAKDAR, 2001, s. 205.

27 TEZİÇ, 1990, s. 35.

28 Her ne kadar idari faaliyetlerin kamu hizmeti üst başlığı altında ele alınmaması gerektiği düşünülmekte ise de bu çalışmada AYM kararlarına paralel olarak kamu hizmeti terimi kullanılmaktadır. Kamu hizmeti terimi idarenin tüm faaliyetleri olarak değerlendirilmelidir.

29 TUTUM, Cahit, “Memurluk Statüsü”, Amme İdaresi Dergisi, Cilt: 5, Sayı: 2 Haziran, (s. 3-10), s. 5. Tutum memurların iktidara bağlı olmasının tehlikeli olduğunu belirtmekte ve tarafsızlığı çok partili sistemlerin temel felsefesiyle ilişkilendirmektedir.

30 ÇїTÇ், 1992, s. 90.

31 KAMAN KARAN, 2003, s. 121. 
gerekir ki, tarafsızlık yükümlülüklerinin kapsamı üstlenilen devlet memurluğu görevine göre de değişebilecektir; nitekim her devlet memurunun ifade açıklamalarının etkisi aynı olmayacaktır ${ }^{32}$.

Devlet memurlarının temel hak ve özgürlüklerinin sınırlanması tarafsızlık yükümlülüğü yanında sadakat ve devlete bağlılık yükümlülüğü çerçevesinde de ele alınmalıdır. Anayasa md. 129 ile devlet memurlarının Anayasa ve kanunlara sadık kalarak faaliyette bulunma yükümlülükleri düzenlenmektedir. DMK'de ise sadakat ve devlete bağlılık yükümlülüğü daha detaylı olarak ele alınmaktadır ${ }^{33}$. DMK md. 6 sadakat yükümlülüğünü ortaya koyarken $\mathrm{DMK}$ md. 7 tarafsızlık ve devlete bağlılık yükümlülüğünü açıklamaktadır. DMK md. 6/1 uyarınca devlet memurları "Türkiye Cumhuriyeti Anayasasına ve kanunlarına sadakatle bağlı kalmak ve milletin hizmetinde Türkiye Cumhuriyeti kanunlarını sadakatle uygulamak zorundadırlar" ve DMK md. 6/2 uyarınca "Türkiye Cumhuriyeti Anayasasına, Atatürk İnkılap ve İlkelerine, Anayasada ifadesi bulunan Türk Milliyetçiliğine sadakatle bağlı" kalacaklarına yemin etmektedirler. DMK md. 7/2 uyarınca ise devlet memurlarının her durumda "Devletin menfaatini koruma" yükümlülüğü altında olduğu ve "Türkiye Cumhuriyeti Anayasasına ve kanunlarına aykırı olan, memleketin bağımsızlığını ve bütünlüğünü bozan Türkiye Cumhuriyeti'nin güvenliğini tehlikeye düşüren herhangi bir faaliyette" bulunamayacakları belirtilmektedir. İlgili maddeler sadakat ve devlete bağlılık yükümlülüğünü ortaya koymakla birlikte, bu yükümlülügün ne anlama geldiğinin ayrıca değerlendirilmesi gerekmektedir. Bu kavramlar doktrinde Anayasa ya da yasalara uygun davranmanın ötesinde bir kural olarak ele alınmaktadır ${ }^{34}$.

32 Noterlik görevinin gerektirdiği niteliğe ilişkin gerçekleştirilen bir değerlendirmede hizmete girmeden önce gerçekleştirilen fiil ve eylemlerin hizmetin tarafsız bir şekilde yürütülmesine engel oluşturabileceğine ilişkin AYM kararı için ayrıca bkz. AYM, E. 2018/89, K. 2019/84, T. 14.11.2019, özellikle bkz. par. 35 .

33 GÖZÜBÜYÜK, Şeref / TAN, Turgut, İdare Hukuku Genel Esaslar I, 11. Basım, Turhan Kitabevi, Ankara, 2016, s. 864. GÖZÜBÜYÜK/TAN “bağlılık” kavramını kullanmaktadırlar.

34 AKILLIOĞLU, Tekin, “Düşünce ve Anlatım Özgürlüğü ve Kamu Görevlileri”, İnsan Hakları ve Kamu Görevlileri, (Yayına Hazırlayan: M. Gülmez), Türkiye ve Orta Doğu Amme İdaresi Enstitüsü, Ankara, 1992, (s. 25-34), s. 31. Benzer şekilde GÖZLER, Kemal, İdare Hukuku, Cilt: 2, Güncellenmiş 3. Bası, Ekin Kitabevi Yayınları, Bursa, 2019, s. 749. 
Sadakat ve devlete bağlılık yükümlülügünün birlikte (birbirlerinin yerine geçer şekilde) kullanıldığı, devletin ideolojisini savunma yükümlülüğü olarak ele alındığı ve devlet memurlarından belirli bir ideoloji doğrultusunda davranmasının beklenmesi olarak değerlendirildiği görülmektedir ${ }^{35}$. Sadakat ve devlete bağlılık yükümlülükleri ayrı da ele alınmaktadır. Bu doğrultuda, sadakat yükümlülüğünün devlete bağl1lık yükümlülüğüne kıyasla daha "yoğun" bir ilişkiyi içerdiği ve "itaat" ilişkisini çağrıştırdığ 1 da belirtilmekte $^{36}$ ve sadakat kavramının hukuk düzenine sadakat olarak ele alındı ̆̆ görülmektedir ${ }^{37}$. Doktrinde, sadakat yükümlülügünün rejime sadakat olarak anlaşılması gerektiği de belirtilmektedir ${ }^{38}$. Ayrıca, sadakat yükümlülüğünün çok geniş olarak ele alındığı ve “itaat etme yükümlülüğü, tarafsızlık, bağlılık yükümlülüğü, gizlilik yükümlüğü ve mesleki etik kurallarına uyma yükümlülüğü” gibi yükümlülükler üzerinden tanımlandığı da tespit edilebilmektedir ${ }^{39}$.

Devlete bağl1lık ise devletin menfaatlerini ön planda tutarak savunma yükümlülüğü üzerinden tanımlanmaktadır ${ }^{40}$. Devlete bağl1lık yükümlülüğünün ülkeye bağl1lık ve millete bağlılık ödevi kavramları üzerinden açıklandı̆̆ı da görülmektedir ${ }^{41}$. Bu doğrultuda ülkeye bağlılık temel olarak ülkenin “Türk ülkesi” olduğunun ve bölünmez bütünlüğünün savunulması ve bu gibi konularda farklı yönde bir görüş bildirilmemesi olarak değerlendirilmektedir ${ }^{42}$. Millete bağlılık ödevi çerçevesinde ise devlet memurlarının milliyetçiliğe aykırı davranış sergilememesi gerektiği belirtilmektedir ${ }^{43}$.

35 KAMAN KARAN, 2003, s. 122.

36 SEVER, Dilşad Çiğdem, “Kamu Görevlilerinin İfade Özgürlüğü ve Disiplin Hukukunun Sinırı”, Prof. Dr. Metin Günday Armağanı, Cilt: 2, Atılım Üniversitesi, Ankara, 2020, (s. 1165-1211), s. 1181.

37 SEVER, 2020, s. 1181. Sadakat kavramının hukuk kurallarına uygun davranma olarak ele alınışı için ayrıca bkz. ULUSOY, Ali D., Yeni Türk İdare Hukuku, Yetkin Yayınları, Ankara, 2019, s. 585.

38 AKYILMAZ, Bahtiyar, “Türk Hukukunda Kamu Görevlilerinin Devlete Sadakat Yükümlülüğü”, Danıştay ve İdari Yargı Günü 149. Yıl Sempozyumu, Danıştay Yayınları No: 93, Ankara, Mayıs 2017, (s. 15-34), s. 26.

39 AKYILMAZ, 2017, s. 17.

40 ULUSOY, 2019, s. 585.

41 GÖZLER, 2019, s. 750.

42 GÖZLER, 2019, s. 750.

43 GÖZLER, 2019, s. 750. 
$\mathrm{Bu}$ açıklamalar doğrultusunda sadakat yükümlülüğünün Anayasa ve kanunlara uygun davranma ve devlete bağlılık yükümlülüğünün ise devlet ideolojisi doğrultusunda hareket etme veya devlet ideolojisine aykırı davranmama olarak tanımlanması söz konusu olabilir. Fakat, devlete bağlılık kapsamında ele alınan ülkenin bölünmez bütünlüğü veya milliyetçilik kavramlarının Anayasa ile güvence altına alındığı (ör. bkz. Anayasa md. 2 ve md. 3) göz önünde tutulduğunda, devlete bağlılık yükümlülüğünün Anayasa ve kanunlara uygun davranma yükümlülüğünden ayrıştırılması kolay olmamaktadır. İki kavramın birbirinden ayrıştırılabilmesi için devlete bağlılık yükümlülügüunün hükümet politikasına bağlılık olarak yorumlanması iddia edilebilecek olsa da devlet memurundan Anayasaya uygun olmayan hükümet politikalarına bağlı olmalarının beklenmesi savunulmamalıdır ${ }^{44}$. Bu doğrultuda devlete bağlılık kavramı hükümete bağlılık olarak anlaşılmamalıdır 45 .

Bu bağlamda hem sadakat hem de devlete bağlılık yükümlülüğünün, Anayasa'da da belirtildiği üzere devlet memurlarının Anayasaya ve kanunlara uygun hareket etme yükümlülüğü olarak anlaşılması en uygun yorum olacaktır. Bu yoruma, tüm vatandaşların bu yükümlülükleri tabi olduğu itirazı ileri sürülebilir. Bu itiraz, özellikle, DMK md. 3 ile devlet memurluğuna giriş için liyakatin esas alınması gerektiğinin belirtilmesi ve tarafsızlık, sadakat ve devlete bağlılık yükümlülüklerinin devlet memurluğu görevine gelindikten sonra ortaya çıkması göz önünde tutulduğunda yerindedir. Nitekim, Anayasa md. 70/2 ile hizmete alınmada görevin gerektirdiği niteliklerden başka bir nitelik aranmadığı belirtilmektedir. Bu bağlamda bu gibi yükümlülüklerin devlet memurluğu statüsünü kazandıktan sonra doğması devlet memurları ile diğer vatandaşların yükümlülüklerinin farklılaştığını göstermektedir. Burada dikkat edilmesi gereken farklılık devlet memurlarının, vatandaşlardan farklı olarak mesleklerini ve devlet memurluğu statüsünü kaybetme ihtimali ile karşı karşıya gelmesidir. Bu sebeple devlet memurlarının diğer vatandaşlara göre Anayasa ve kanunlara uygun davranma konusunda daha özenli davranma yükümlülüğü altında olduğu tespit edilebilir. Bu doğrultuda, ifade

\footnotetext{
44 Devlet memurlarının Anayasa'ya aykırı olan ve iptal edilmemiş bir kanunu kanunilik ilkesi doğrultusunda uygulaması gerekliliği bu çalışma çerçevesinde değerlendirilmemektedir.

45 Benzer şekilde bkz. GÖZLER, 2019, s.749.
} 
özgürlüğüne sadakat ve devlete bağl1lık yükümlülügü gerekçesi ile getirilen sınırlamaların, devlet memurlarının Anayasaya ve kanunlara uygun davranmasını amaçladığı düşünülmelidir. Sadakat ve devlete bağlılık yükümlülüklerinin devlet memurlarının ifade özgürlüklerini sınırlandırma gerekçesi olarak kullanıldığı düşünüldüğünde, bu gibi bir amacın kabulü ifade özgürlüğünün sınırlarının öngörülebilirliğine katkı sağlayacaktır.

Tarafsızlık, sadakat ve bağlılık yükümlülükleri devlet memurlarının ifade özgürlüklerini sınırlama gerekçesini oluşturabilmekle birlikte, Danıştay’ın kararlarında tarafsızlık, sadakat ve bağlılık yükümlülüklerine ilişkin açıkça değerlendirme yapmadığı; fakat devlet memurlarının ifade özgürlüklerinin sınırlandırılması konusunda titiz değerlendirme yaptığ 1 ve özgürlükçü yaklaşım benimsediği görülmektedir. Danıştay 5 . Dairesi, devlet memuru olan davacının siyasi ve ideolojik amaçlı ifadeler kullandığı iddia edilen yeni yıl tebrik kartının basında yer alması sebebiyle açılan soruşturma sonucunda yargılandığı ve soruşturma sırasında görüşünü basında savunduğu gerekçeleriyle hakkında verilen disiplin cezasının iptaline ilişkin davada, devlet memurunun görevden alınmasının asıl nedeninin yeni yıl tebrik kartı olduğunu belirterek karta yönelik bir inceleme gerçekleştirmiştir" ${ }^{46}$. Danıştay, kartın içeriğinde yazan "Yeni Yılınızı insan haklarının çiğnenmediği, düşünce suçunun olmadı̆̆g; demokrasinin tüm kurumlarlyla işler hale geldiği, emekçi sınıfların da kapitalist sınıflar gibi örgütlenip devlet yönetiminde söz sahibi oldukları, milli gelirin adli dă̆ıtıldı̆̆g, sosyal adaletin gerçekleştiği; ekonomizmin IMF'nin, holdinglerin, para babalarının çıkarlarına göre değil, çalışan geniş halk kitlelerinin çıkarlarına göre yönetildiği; kalkınmış, çăgdaş uygarlık düzeyine ulaşmış, tam bağımsızlı̆̆ın, özgürlüğün, barışın, kardeşliğin, dostluğun, sevginin egemen olduğu yepyeni bir Türkiye'nin özlemiyle kutlartm" biçimindeki ifadelerin herhangi bir siyasi parti veya örgüt lehine ya da aleyhine ifadeler olmadığı ve herhangi bir ideolojiyi yerme ya da benimsetme amacı güdülmediğini belirterek tebrik kartının "siyasi ve ideolojik amaçla beyanda bulunmama" yasağına

46 Danıştay 5. Daire, E. 1986/1723, K. 1991/933, T. 22.05.1991. 
girmediğine hükmetmiştir ${ }^{47}$. İHAS ve Anayasa çerçevesinde de değerlendirme yapan Danıştay, ifade özgürlüğünü “demokratik toplum olmanın başta gelen temel ilkelerinden birisi olarak" kabul etmekte ve kişinin düşünce ve kanaatlerini dile getirdiği bu karttaki ifadelerin gerek İHAS md. 10 gerekse AY md. 26'da belirtilen ifade özgürlügüüü sınırlama sebeplerine uygun düşmediğini belirtmektedir ${ }^{48}$. Önem teşkil eden bir diğer karar ise, Danıştay’ın devlet memurlarının ifade özgürlüğünün sınırlanabilir olduğunu kabul etmekle birlikte, sınırlamaları ölçüsüz bulduğu kararıdır. Danıştay 8. Dairesi, devlet memurunun basına valiliği eleştiren bir demeç vermesi üzerine verilen kademe ilerlemesinin durdurulması cezası hakkında değerlendirme yaptı̆̆ bir kararında, devlet memurlarının ifade özgürlüklerini kullanmasının Anayasal bir hak olduğunu; fakat ifade özgürlüğünün tüm bireylerce eşit ve aynı yoğunlukta kullanılmasının mümkün olmadığını ve devlet memurlarının bu özgürlüklerini "daha ölçülü ve daha özenli”" kullanmaları gerektiğini belirterek disiplin cezası verilmesini yerinde bulmak ile birlikte, suç ile ceza arasında adil bir denge bulunmadı̆̆ gerekçesi ile daha hafif bir cezanın verilmesi gerektiğini belirtmektedir ${ }^{49}$. Yakın tarihli kararlarında da Danıştay'ın başta Anayasa md. 26 ve İHAS md. 10 olmak üzere ifade özgürlüğüne getirilen Anayasal güvenceleri değerlendirmek suretiyle "salt basın açıklamasına katılma” fiilinin "siyasi parti yararına fiilen faaliyette bulunmak" fiili olarak değerlendirilemeyeceğine hükmettiği de görülmektedir ${ }^{50}$. Bir başka yakın tarihli kararında ise Danıştay, İHAM ve AYM kararlarına atıf yapmak suretiyle "salt siyasi parti toplantısına katılma" fiilinin

47 Danıştay 5. Daire, E. 1986/1723, K. 1991/933, T. 22.05.1991. Karş1 oy yazısında ise ifade özgürlüğünün "tarafsızlık ve Devlete bağlılık" ilkeleri çerçevesinde devlet memurları bakımından sınırlandırıldığı ve bu sınırın hizmetin özelliğine uygun olduğu belirtilmektedir.

48 Danıştay 5. Daire, E. 1986/1723, K. 1991/933, T. 22.05.1991. Bu karar Danıştay’ın Anayasa Md. 90/son uyarınca İHAS'ın iç hukuk açısından uygulanması gerektiği değerlendirmeleri bakımından da önem teşkil etmektedir.

49 Danıştay 8. Daire, E. 1993/1617, K. 1993/4212, T. 14.12.1993. Disiplin cezası tesis edilmesine sebep olan fiil DMK md. 15'te düzenlenmektedir. İlgili madde şu şekildedir: "Devlet Memurları, kamu görevleri hakkında basına, haber ajanslarına veya radyo ve televizyon kurumlarına bilgi veya demeç veremezler. Bu konuda gerekli bilgi ancak bakanın yetkili kılacağı görevli illerde valiler veya yetkili kılacağı görevli tarafından verilebilir."

50 12. Daire, E. 2016/1803, K. 2018/408, T. 05.02.2018. Benzer şekilde ve Anayasa hükümlerine ek olarak İHAM ve AYM kararlarının da ele alındığı Danıştay kararı için bkz. 12. Daire, E. 2013/319, K. 2016/6344, T. 13.12.2016. 
"siyasi parti yararına fiilen faaliyette bulunmak" fiili olarak değerlendirilmemesi gerektiğini belirtmektedir ${ }^{51}$.

Devlet memurlarının ifade özgürlüklerinin sınırlandırılması tarafsızlık, sadakat ve bağlılık yükümlülükleri ile gerekçelendirmekle birlikte, bu sınırlamaların sınırının olmadığını söylemek mümkün değildir. Nitekim, belirtildiği üzere ifade özgürlüğünün sınırlandırılması da temel hak ve özgürlüklerin sınırlanması rejimine tabi olacaktır ve devlet memurlarının ifade özgürlüklerine getirilen sınırlamaların Anayasa md. 13 ile öngörülen sınırlamalara tabi olacağının altı çizilmelidir. $\mathrm{Bu}$ doğrultuda, kamu görevlilerine getirilen sinırlamaların kanun ile öngörülmesi, ${ }^{52}$ Anayasa md. 26/2' de belirtilen sebeplerle bağlı olması ve demokratik toplum gerekliliklerine ve ölçülülük ilkesine aykırı olmaması gerekmektedir ${ }^{53}$. Bu sınırlamalar, AYM bireysel başvuru kararları incelenirken ayrıca değerlendirilecektir.

\section{ANAYASA MAHKEMESİ BİREYSEL BAŞVURU KARARLARININ İNCELENMESİ VE DEĞERLENDİRILMESI}

Çalışmanın bu kısmında Hasan Güngör, Hasan Güngör (2) ve Zeki Çınar başvuruları, (i) olaylar ve olgular, (ii) ilgili hukuk ve (iii) Anayasa Mahkemesinin incelemesi ve gerekçesi alt başlıklarında incelenecektir. AYM'nin incelemesi ve gerekçesi ise (i) kanunilik ve meşru amaç ve (ii) demokratik toplum düzeninin gereklerine uygunluk değerlendirmesi alt başlıklarında ele alınmaktadır. Bu çalışma kapsamında AYM kararlarının değerlendirilmesi ve değerlendirme yapılırken İnsan Hakları Avrupa Mahkemesi (“IHAM”) kararlarından yararlanılması amaçlanmaktadır.

51 Danıştay 12. Daire, E. 2016/ 3449, K. 2016/6362, T. 13.12.2016. Sever, AYM kararlarına atıf yapılmasının Danıştay’ın AYM içtihadını takip ettiğini gösterdiğini belirtmektedir. Bkz. SEVER, 2020, s. 1184.

52 Devlet memurlarının fiil ve eylemleri karşısında öngörülen disiplin cezalarında kanuniliğe ilişkin Anayasa md. 2, md. 38 ve md. 128'in de değerlendirilmesine ilişkin ayrıca bkz. SEVER, 2020, s. 1179.

53 Anayasa md. 13'ün kamu görevlilerinin ifade özgürlüklerine getirilen sınırlamaların sınırları bakımından ele alındığı karar için bkz. AYM, E. 2016/7, K. 2017/171, T. 13.12.2017. 


\section{A. Olaylar ve Olgular}

Hasan Güngör başvurusu ilköğretim okulunda sınıf öğretmeni olan devlet memuru Hasan Güngör'e verilen disiplin cezasının ifade özgürlüğü açısından değerlendirilmesine ilişkindir. Hasan Güngör, Demokrasi Platformunun çağrısı üzerine Demokratik Toplum Partisinin düzenlemiş olduğu basın açıklamasına katılmıştır ${ }^{54}$. Başvurucu hakkında basın açıklamasına katılmak suretiyle siyasi parti faaliyetine katıldığı gerekçesi ile başvurucu hakkında disiplin soruşturması başlatılmıştır ve soruşturma sonucunda "basın açıklamasına katılmanın parti eylemine katılmış sayılması" gerekçesi ile hakkında DMK md. 125 (D) (o) uyarınca 1 yıl süre ile kademe ilerlemesinin durdurulması cezası verilmiştir ${ }^{55}$. Disiplin cezasının iptali istemiyle açılan davada Diyarbakır 1. İdare Mahkemesi basın açıklamasının parti faaliyeti olması ve açıklamaya katılmanın parti faaliyeti anlamına gelmesi gerekçesiyle disiplin cezasının hukuka uygun olduğuna karar vermiş, bu karar Danıştay tarafından onanmış ve ayrıca karar düzeltme istemi Danıştay tarafindan reddedilmiştir ${ }^{56}$.

Hasan Güngör (2) başvurusu Hasan Güngör'e verilen disiplin cezasının ifade özgürlüğü açısından değerlendirilmesine ilişkindir. Hasan Güngör, Demokratik Toplum Partisinin binasında Diyarbakır ceza infaz kurumundaki şartlara dikkat çekmek için açlık grevinde bulunan kişileri parti binasında ziyaret etmiştir ve başvurucu hakkında DMK md. 125 (D) (o) uyarınca 1 yıl süre ile kademe ilerlemesinin durdurulması cezası verilmiştir $^{57}$. Disiplin cezasının iptali istemiyle açılan davada Diyarbakır İdare Mahkemesi parti binasında gerçekleştirilen grevin parti eylemi teşkil etmesi ve ziyaretin grevi destekleme yani parti faaliyetine destek verme anlamını taşıması gerekçesiyle disiplin cezasının hukuka uygun olduğuna karar vermiş ve bu karar Danıştay tarafından

\footnotetext{
54 Hasan Göngör, par. 8.

55 Hasan Göngör, par. 9.

56 Hasan Göngör, par. 10-12.

57 Hasan Göngör (2), par. 10.
} 
onanmıştır ${ }^{58}$. Ayrıca belirtmek gerekir ki başvurucu, Hasan Güngör başvurusuna konu olay nedeniyle fiilin tekerrür etmesi sebebiyle memuriyetten ihraç edilmiştir ${ }^{59}$.

Zeki Çınar başvurusu Bursa Vergi Dairesi Başkanlığı Diğer Vergiler Müdürlüğünde bilgisayar işletmeni olan başvurucu Zeki Çınar'a verilen disiplin cezasının ifade özgürlüğü açısından değerlendirilmesine ilişkindir. Zeki Çınar hakkında Partizan isimli topluluğun etkinliklerine katıldığı yönündeki ihbar mektubu ve başvurucunun Partizan isimli topluluk tarafindan düzenlenen piknikte "Biz halkız. Gelecek ellerimizdedir. Partizan.”, “Oy verme, onay verme, oyuna gelme. Partizan.” yazılı pankartların önünde oturduğu fotoğrafın gönderilmesi üzerine disiplin soruşturması başlatılmıştır ${ }^{60}$. Gerçekleştirilen disiplin soruşturması kapsamında Zeki Çınar'ın (i) Partizan isimli topluluk tarafından düzenlenen pikniğe katılması, (ii) 1 Mayıs 2005 yılında gerçekleştirilen toplantıya katılarak "Partizan" ve "İşçi Köylü” pankartları arasında yürüyerek slogan atması ve (iii) 2004 yılında gerçekleştirilen NATO zirvesi protestolarına katılması birlikte ele alınarak Zeki Çınar hakkında DMK md. 125 (D) (o) uyarınca 1 yıl süre ile kademe ilerlemesinin durdurulması cezası verilmiştir ${ }^{61}$. Disiplin cezasının iptali istemiyle açılan davada, Bursa 1. İdare Mahkemesi Partizan isimli topluluğun yasa dişı olduğunun ve Partizan isimli bir siyasi parti olduğunun ispat edilememesi gerekçesi ile davanın kabulüne karar vermekle birlikte, Danıştay 12. Dava Dairesi idarenin temyiz istemini kabul ederek piknik sırasında açılan pankartların "seçimlere katılan tüm siyasi partilerin zararına olacak şekilde faaliyet" teşkil etmesi gerekçesi ile ilk derece mahkemesinin kararının bozulmasına karar vermiştir ${ }^{62}$. Bursa 1. İdare Mahkemesi de bozma doğrultusunda verilen kararı onamıştır ${ }^{63}$.

\footnotetext{
58 Hasan Göngör (2), par. 11-13.

59 Hasan Göngör (2), par. 15.

60 Zeki Çınar, par. 9, 10, 13.

61 Zeki Çınar, par. 11-13.

62 Zeki Çınar, par. 14-15.

63 Zeki Çınar, par. 16.
} 


\section{B. İlgili Hukuk}

Üç başvuruda da ilgili hukuk olarak disiplin cezası yaptırımının hukuksal sebebi olan DMK md. 7 ve md. 125 gösterilmektedir. ${ }^{64}$ AYM, Hasan Güngör başvurusunda DMK md. 135 ' $\mathrm{e}^{65}$ ve Hasan Güngör (2) başvurusunda Anayasa md. 68/5 ve devlet memurluğundan çıkarma cezasını gerektiren fiil ve hallerin düzenlendiği DMK md. 125/E’nin ilgili diğer alt bentlerine de atıf yapmaktadır ${ }^{66}$.

Hasan Güngör (2) başvurusunda ve Zeki Çınar başvurusunda, Hasan Güngör başvurusundan farklı olarak ulusal hukuk ve uluslararası hukuk başlıklandırılmasına gidildiği ve İHAM içtihatlarına uluslararası hukuk başlı̆̆ altında yer verildiği görülmektedir. Hasan Güngör (2) başvurusunda İHAM'ın Kara/Türkiye kararının özeti paylaşılmakta ${ }^{67}$ ve Hasan Güngör (2) ve Zeki Çınar başvurularında ifade özgürlüğüne ilişkin gerçekleştirilen incelemelerde değerlendirilecek hususlara ve devletlerin takdir marjına ilişkin olarak İsmail Sezer/Türkiye, Ahmed vd./Birleşik Krallık, Vogt/Almanya,

64 Hasan Güngör, par. 15-16; Hasan Güngör (2), par. 17-19; Zeki Çınar, par. 18-19.

65 Hasan Güngör, par. 17. Atıf yapılan DMK maddesi şu şekildedir: "Disiplin amirleri tarafından verilen uyarma, kınama ve aylıktan kesme cezalarına karşı disiplin kuruluna, kademe ilerlemesinin durdurulması cezasına karşı yüksek disiplin kuruluna itiraz edilebilir. İtirazda süre, kararın ilgiliye tebliği tarihinden itibaren yedi gündür. Süresi içinde itiraz edilmeyen disiplin cezaları kesinleşir. İtiraz mercileri, itiraz dilekçesi ile karar ve eklerinin kendilerine intikalinden itibaren otuz gün içinde kararlarını vermek zorundadır. İtirazın kabulü hâlinde, disiplin amirleri kararı gözden geçirerek verilen cezayı hafifletebilir veya tamamen kaldırabilirler. Disiplin cezalarına karşı idari yargı yoluna başvurulabilir."

66 Hasan Güngör (2), par. 16, 19. Anayasa md. 68/5 uyarınca "Hâkimler ve savcılar, Sayıştay dâhil yüksek yarg1 organları mensupları, kamu kurum ve kuruluşlarının memur statüsündeki görevlileri, yaptıkları hizmet bakımından işçi niteliği taşımayan diğer kamu görevlileri, Silahlı Kuvvetler mensupları ile yükseköğretim öncesi öğrencileri siyasi partilere üye olamazlar." Atıf yapılan DMK maddesi şu şekildedir: "E- Devlet memurluğundan çıkarma: Bir daha Devlet memurluğuna atanmamak üzere memurluktan çıkarmaktır. Devlet memurluğundan çıkarma cezasını gerektiren fiil ve haller şunlardır: a) İdeolojik veya siyasi amaçlarla kurumların huzur, sükûn ve çalışma düzenini bozmak, boykot, işgal, kamu hizmetlerinin yürütülmesini engelleme, işi yavaşlatma ve grev gibi eylemlere katılmak veya bu amaçlarla toplu olarak göreve gelmemek, bunları tahrik ve teşvik etmek veya yardımda bulunmak, (1) b) Yasaklanmış her türlü yayını veya siyasi veya ideolojik amaçlı bildiri, afiş, pankart, bant ve benzerlerini basmak, çoğaltmak, dağıtmak veya bunları kurumların herhangi bir yerine asmak veya teşhir etmek, c) Siyasi partiye girmek [...] 1) Siyasi ve ideolojik eylemlerden arananları görev mahallinde gizlemek"

67 Hasan Güngör (2), par. 20. Bu kararın özetinin paylaşılması kararın içeriğinin başvuruya konu olay ve olgularla (o dönemde gerçekleştirilen açlık grevine ilişkin gösterilen dayanışma karşısında idari para cezası verilmesi) benzerlik göstermesine ilişkin olabilir. Atıf yapılan karar künyesi şu şekildedir: Kara/Türkiye, Başvuru No: 2766/04, 30.06.2009. 
Otto/Almanya kararlarına ve devlet memurlarına sorumluluk yüklenmesinin meşru olmasına ve fakat memurların da ifade özgürlüğünü haiz olduğuna ilişkin olarak İsmail Sezer/Türkiye ve Vogt/Almanya kararlarına atıf yapılmaktadır ${ }^{68}$. Fakat belirtmek gerekir ki, ilgili İHAM kararları, AYM'nin başvuruyu inceleme aşamasında ele alınmamaktadır. Hasan Güngör başvurusunda ise İHAM kararlarına ilgili hukuk başlığı altında yer verilmemekle birlikte AYM'nin söz konusu İHAM kararlarından inceleme aşamasında faydalandığı görülmektedir ${ }^{69}$. Bu noktada belirtmek gerekir ki, AYM'nin Hasan Güngör kararında inceleme sırasında İHAM'dan faydalanırken daha sonraki kararlarında kendi içtihadına atıf yaparak İHAM kararlarını ilgili hukuk başlığında destek ölçü norm olarak kullanması bireysel başvuru içtihadının gelişmiş olduğunu göstermesi bakımından olumlu olarak değerlendirilebilir.

\section{Anayasa Mahkemesinin İncelemesi ve Gerekçesi}

AYM, başvurularda ifade özgürlüğünün ihlal edildiği iddialarını kabul edilebilir bulmakta $^{70}$ ve esas yönünden değerlendirmeyi müdahalenin varlığ 1 ve müdahalenin ihlal oluşturup oluşturmadığı başlıklarında gerçekleştirmektedir. Değerlendirmesini İHAS'ta öngörülen sinırlamalara paralel şekilde gerçekleştiren AYM, Hasan Güngör başvurusunda müdahalenin ihlal oluşturup oluşturmadığı değerlendirmesini (i) kanunilik, (ii) meşru amaç ve (iii) demokratik toplum düzeninde gerekli olma ve ölçülülük başlıkları altında gerçekleştirirken, Hasan Güngör (2) ve Zeki Çınar başvurularında (i) kanunilik, (ii) meşru amaç ve (iii) demokratik toplum düzeninin gereklerine uygunluk başlıkları altında gerçekleştirmektedir. Zeki Çınar başvurusunda AYM'nin özel olarak (i) demokratik toplum düzenin gerekleri ve ifade özgürlüğü, (ii) kamu görevlilerinin ifade

68 Hasan Güngör (2), par. 21-22; Zeki Çınar, par. 20-21. Atıf yapılan karar künyeleri şu şekildedir: İsmail Sezer/Türkiye, Başvuru No: 36807/07, 24.03.2015, par. 28, 52; Ahmed vd./Birleşik Krallık, Başvuru No: 22954/93, 02.09.1998, par. 53, 54; Vogt/Almanya [BD], Başvuru No: 17851/91, 26.09.1995, par. 51-53; Otto/Almanya (k.k.), Başvuru No: 27574/02, 24.11.2005.

69 Hasan Güngör, par. 29, 44, 46, 48-49. Hasan Güngör (2) ve Zeki Çınar kararlarından ayrı olarak atıf yapılan kararlar şu şekildedir: Handyside/Birleşik Krallık, Başvuru No: 5493/72, 07.12.1976; Başkaya ve Okçuoğlu/Türkiye, Başvuru No: 23536/94 ve 24408/94, 08.07.1999; Kayasu/Türkiye, Başvuru No: 64119/00 ve 76292/01, 13.11.2008.

70 Hasan Güngör, par. 22; Hasan Güngör (2), par. 31; Zeki Çınar, par. 25. 
özgürlüğü ve (iii) kamu görevlerinin ödev ve sorumlulukları ile ifade özgürlüğü arasında dengeleme alt başlıklandırmalara gittiği görülmektedir. Bu doğrultuda, AYM'nin her bir kararında bir önceki kararına göre daha sistematik bir inceleme gerçekleştirdiği yorumu yapılabilir.

\section{Kanunilik ve Meşru Amaç Değerlendirmesi}

AYM, kararlarında DMK md. 7 ve md. 125 doğrultusunda müdahalenin kanunilik koşulunun sağlandığını belirtmektedir ${ }^{71}$. İfade özgürlüğünün sınırlandırılmasına yönelik meşru amaç bulunup bulunmadığı değerlendirilirken ise, AYM, Hasan Güngör başvurusunda disiplin cezasının Anayasa md. 26/2'de sayılan amaçları hedeflediğinin kabul edilebileceğini; fakat bu durumun müdahalenin gerekliliği ile birlikte tartışılması gerektiğini ifade etmektedir ${ }^{72}$. Hasan Güngör başvurusunda AYM, ifade özgürlüğüne yapılan müdahalenin meşru sayılabilmesi için "milli güvenlik, kamu düzeni, suç işlenmesinin önlenmesi, genel sağlık, genel ahlak ile başkalarının hak ve özgürlüklerinin korunması" sebebiyle yapılması gerektiğini belirtmekte, bu başlık altında sebeplere ilişkin özellikli bir değerlendirme yapmamakta ve "kamu düzeni" sebebine ilk derece mahkemesi kararının gerekçesini belirtirken değinmektedir ${ }^{73}$. AYM, Hasan Güngör (2) başvurusunda müdahalenin kamu düzeninin ve Zeki Çınar başvurusunda kamu düzeninin ve güvenliğinin korunmasına yönelik olduğunu belirterek müdahalenin meşru amac1 olduğunu kabul etmektedir ${ }^{74}$.

71 Hasan Güngör, par. 37; Hasan Güngör (2), par. 35; Zeki Çınar, par. 29. Belirtmek gerekir ki Hasan Güngör başvurusunda yalnızca DMK Md. 125'e atıf yapılmaktadır.

72 Hasan Güngör, par. 38-40.

73 Hasan Güngör, par. 38-39.

74 Hasan Güngör (2), par. 36; Zeki Çınar, par. 30. Belirtmek gerekir ki, Hasan Güngör başvurusunda meşru amaç değerlendirmesi sonradan gerçekleştirilmemektedir. 
Kanunilik değerlendirmesi yaparken AYM'nin şekli bir kanun olmasını yeterli gördüğü ve kanunilik koşulunun sağlanıp sağlanmadığını detaylı olarak değerlendirmediği görülmektedir. Hukuk devletinde kanuni düzenlemelerin "hem kişiler hem de idare yönünden herhangi bir duraksamaya ve kuşkuya yer vermeyecek şekilde açık, net, anlaşı1ır, uygulanabilir ve nesnel olması, ayrıca kamu otoritelerinin keyfî uygulamalarına karşı koruyucu önlem içermesi” gerektiği AYM kararlarında belirtilmektedir $^{75}$. AYM, bireysel başvuru kararlarında müdahalenin bir kanuna dayanmasının yetmeyeceğini ve dayanılan kanunun "belirlilik” ve “öngörülebilirlik” gibi nitelikleri haiz olması gerektiğini dile getirmektedir ${ }^{76}$. Bu doğrultuda devlet memurunun da kendisine düşen yükümlülükleri öngörmesi ve hangi davranışına ne gibi bir hukuksal sonucun bağlandığını bilmesi gerekmektedir ${ }^{77}$. Fakat üç başvuruda da AYM, devlet memurlarının ifade özgürlüklerinin sınırlandırılmasını öngören DMK md. 7 ve md. 125'i bu yönden değerlendirmemektedir. Oysa, DMK md. 125 ile öngörülen "herhangi bir siyasi parti yararına veya zararına fiilen faaliyette bulunmak" ya da DMK md. 7 ile getirilen "herhangi bir siyasi parti, kişi veya zümrenin yararını veya zararını hedef tutan bir davranışta bulunmama" yasağının belirlilik ve öngörülebilirlik ilkeleri bakımından ele alınması önemlidir. Nitekim, bu hükümlerin kapsamında bulunan davranışların neler olduğu ya da devlet memurlarının görevleri dışındaki ifadelerinin bu madde kapsamında sayılıp sayılmayacağı gibi konular tartışılması gereken hususlardır. Lafzi olarak değerlendirildiğinde, "herhangi bir” açıklamanın DMK kapsamında kalabileceği, DMK ile mutlak bir yasak öngörüldüğü ve bu sebeple ilgili hükümlerinin belirli ve öngörülebilir olduğu yorumu yapılabilir ${ }^{78}$. Fakat, çok geniş bir yasak öngören bu hükümlerin Anayasa md. 26/2 ile öngörülen sinırlama sebepleri ile tamamen uyumlu olduğunu ve Anayasa md. 26/2 ile öngörülen sınırlama sebeplerinin bu denli geniş bir yasağı haklı kıldığını söylemek de mümkün gözükmemektedir.

75 AYM, E.2015/41, K.2017/98, T. 04.05.2017, par. 153.

76 Örn. bkz. Youtube LLC Corporation Service Company ve diğerleri, Başvuru No: 2014/4705, 29.05.2014, par. 56.

77 Bireylere ilişkin benzer şekilde bkz. AYM, E. 2016/7, K. 2017/171, T. 13.12.2017, par. 10.

78 "Her ne suretle olursa olsun" ifadesinin mutlak yasak ifade ettiğine ilişkin bkz. AYM, E. 2016/7, K. 2017/171, T. 13.12.2017, par. 18 . 
AYM'nin meşru amaç değerlendirmesi ayrı bir inceleme konusudur. Meşru amacın varlığı, müdahalenin Anayasa'da öngörülen sınırlama sebeplerine ulaşma amacı söz konusu ise kabul edilmelidir ${ }^{79}$. Genel olarak, AYM'nin meşru amaç değerlendirmesini yüzeysel olarak yaptığı belirtilmekte ${ }^{80}$ ve Anayasa'da yazılan sebeplerin şekli olarak aranması ve somut olay özelinde bir değerlendirme gerçekleştirilmemesi eleştirilmektedir ${ }^{81}$. AYM'nin söz konusu kararlarda da meşru amaç koşulunun karşılanıp karşılanmadığını detaylı olarak değerlendirmediği görülmektedir. Oysa belirli ifadelerin kullanılması ile kamu düzeninin zarar göreceği yönünde "soyut ihtimallere ve genellemelere" dayanılması, ifade özgürlüğüne zarar verebilir ${ }^{82}$. Bu doğrultuda, kamu düzeni kavramının ele alınması ve disiplin cezasının kamu düzenini sağlamaya ne ölçüde katkıda bulunduğunun ayrıca değerlendirilmesi gerekmektedir ${ }^{83}$. Soyut nitelikli, ${ }^{84}$ esnek ve belirsiz bir kavram olduğu belirtilen kamu düzeni klasik olarak belirli bir düzenin ve barışın hâkim olması olarak nitelendirilmektedir ${ }^{85}$. Temel hak ve özgürlüklerin kullanılabilmesi için gerekli olduğu belirtilen kamu düzeni " "hak ve özgürlüklerin kullanılabilir kılındığı bir düzen” olarak tanımlanmalıdır ${ }^{87}$. Bu doğrultuda, AYM'nin

79 İNCEOĞLU, Sibel, "Hak ve Özgürlükleri Sınırlama ve Güvence Rejimi”, İnsan Hakları Avrupa Sözleşmesi ve Anayasa: Anayasa Mahkemesine Bireysel Başvuru Kapsamında Bir İnceleme, (der. S. İnceoğlu), 3. Basım, Beta, İstanbul, Ekim 2013, (s. 23-52), s. 27.

80 KARAN, Ulaş, İfade Özgürlüğü Anayasa Mahkemesine Bireysel Başvuru El Kitapları Serisi 2, Avrupa Konseyi Ankara Program Ofisi, Ankara, Nisan 2018, s. 143.

81 ŞİINN, Tolga, Anayasa Mahkemesi Kararları Işı̆̆ında Bireysel Başvuru Hakkı, On İki Levha Yayınc1lık, İstanbul, Ekim 2015, s. 207.

82 SUNAY, 2001, s. 85.

83 Zeki Çınar başvurusunda kamu güvenliği de meşru amaç olarak gösterilmektedir; fakat somut olaylarda kamunun güvenliğine ilişkin değerlendirme yapılması gereken bir hususa rastlanamadığından esas olarak kamu düzeni kavramının değerlendirilmesi gerekmektedir.

84 SUNAY, 2001, s. 80.

85 TANÖR, 1969, s. 137-138. Benzer şekilde DURAN, Lütfi, İdare Hukuku Ders Notları, İstanbul Üniversitesi Yayınları, Fakülteler Matbaası, İstanbul, 1982, s. 249.

86 Benzer şekilde YAYLA, Yıldızhan, İdare Hukuku, 2. Basım, Beta, İstanbul, 2010, s. 38. Ayrıca bkz. OKAY TEKİNSOY, Özge, İdare Hukukunda Kamu Düzeni Kavramı, On İki Levha Yayıncılı, İstanbul, Mart 2011, s. 17, 37-38.

87 ODER, Burak, "Regülasyon Kavramı Üzerine Bir Deneme”, Ali Ülkü Azrak 75. Yaş Armağanı, İstanbul, Kasım 2008, s. 247, dipnot 29. AYM de "kamu düzeninin sağlanmadığı bir ortamda, hak ve özgürlüklerden gereği gibi yararlanılmasının” mümkün olmadığını ifade etmektedir. Bkz. AYM, E. 2015/19, K. 2015/17, T.18.02.2015. 
somut olayda devlet memurlarına verilen disiplin cezaları ile tarafsızlık yükümlülügüünün unsurları doğrultusunda gerek devlet memurlarının gerekse kamu hizmetinden yararlanan vatandaşların temel hak ve özgürlüklerinin kullanabildiği bir düzenin yaratılmasının amaçlanıp amaçlanmadığını değerlendirmesi beklenebilir.

\section{Demokratik Toplum Düzeninin Gereklerine Uygunluk Değerlendirmesi}

AYM, değerlendirmelerinde ifade özgürlüğünün kapsamını ve önemini ortaya koymaktadır. $\mathrm{Bu}$ bağlamda ifade özgürlüğü "kişinin haber ve bilgilere, başkalarının fikirlerine serbestçe ulaşabilmesi, düşünce ve kanaatlerinden dolayı kınanamaması ve bunları tek başına veya başkalarıyla birlikte çeşitli yollarla serbestçe ifade edebilmesi, anlatabilmesi, savunabilmesi, başkalarına aktarabilmesi ve yayabilmesi” olarak tanımlanmakta ve muhalif olan düşünceler de dâhil olmak üzere her türlü düşünceye ilişkin olarak ifade özgürlügünün kullanılabilmesi demokratik düzenin gereklerinden olarak nitelendirilmektedir ${ }^{88}$. AYM, ifade özgürlüğünün önemini ortaya koyarken, ifade özgürlüğünün demokratik toplumun temellerinden biri olduğunu, gerek bireyin gerekse toplumun gelişmesi için vazgeçilmez ve demokrasi için "yaşamsal önemde" olduğunu ve toplumsal ve siyasal çoğulculuğun sağlanabilmesi için gerekli olduğunu belirtmektedir ${ }^{89}$. AYM'nin ifade özgürlüğünün önemini detaylı olarak ve giriş bölümünde belirtilen hususlara paralel şekilde ortaya koyması önem arz etmektedir. İfade özgürlüğüne önem veren bu yaklaşım ile birlikte, ifade özgürlüğüne getirilen sınırlamaların yaratabileceği ve bireylerin demokratik tartışmaya katkı sağlayacak fikirlerini paylaşmaktan çekinmelerine yol açan ürpertici/caydırıcı etkinin (“chilling effect”) önüne geçilebilir" 90 .

88 Hasan Güngör (2), par. 37; Zeki Çınar, par. 31. Belirtmek gerekir ki, Hasan Güngör başvurusunda da ifade farklılığı olmakla birlikte aynı tanım verilmektedir. Hasan Güngör, par. 27, 29-30.

89 Hasan Güngör, par. 28-30, 45; Hasan Güngör (2), par. 37; Zeki Çınar, par. 31. Belirtmek gerekir ki, Zeki Çınar başvurusunda yaşamsal önemden bahsedilmemektedir. Hasan Güngör (2) başvurusuyla birebir aynı ifadeler kullanılmasına rağmen bu ifadenin yer almamasının sebebi, kopyalama hatası olarak görülüp eleştirilebilir.

90 Dondurucu etkiye ilişkin olarak bkz. TEZCAN / ERDEM / SANCAKDAR vd., 2018, s. 469. 
AYM kararlarında ifade özgürlüğünün kapsamı ve önemi değerlendirildikten sonra ifade özgürlüğünün sınırlanabilir bir hak olduğu ve fakat bu sınırlamanın Anayasa md. 13 doğrultusunda demokratik toplum düzeninin gereklerine uygun olması gerektiği belirtilmektedir ${ }^{91}$. Hasan Güngör ve Hasan Güngör (2) başvurularında demokratik toplum düzenine aykırı olmama kriteri ile birlikte ölçülülük kriterinin ele alınması gerektiği ve bu iki kriterin aralarında sıkı bir ilişki olduğu özel olarak ifade edilmektedir ${ }^{92}$. Başvurularda demokratik toplum düzeninin gereklerine uygun olma kriterinin farklı şekillerde ele alındığı görülmektedir. Demokratik toplum düzenine uygunluk kriteri Hasan Güngör başvurusunda, “çoğulculuk, hoşgörü ve açık fikirlilik" üzerinden tanımlanırken, ${ }^{93}$ Hasan Güngör (2) ve Zeki Çınar başvurularında bu kavramlar demokrasi kavramına ilişskin olarak ele alınmakla birlikte, ${ }^{94}$ AYM, temel hak ve özgürlüklere müdahalenin demokratik toplum düzeninin gereklerine uygun olabilmesi için "zorunlu bir toplumsal ihtiyacı" karşılaması ve "orantılı" olması gerektiğini belirtmektedir ${ }^{95}$. Zorunlu bir toplumsal ihtiyacın karşılanması için müdahalenin elverişli, başvurulacak en son çare ve alınacak en hafif önlem olması ve orantılı bir müdahale olduğunun kabulü için "bireyin hakkı ile kamunun menfaatleri veya müdahalenin amacı başkalarının haklarını korumak ise diğer bireylerin hak ve menfaatleri arasında adil bir dengenin" kurulmuş olması $\operatorname{aranmaktadır}^{96}$.

91 Hasan Güngör, par. 43; Hasan Güngör (2), par. 38; Zeki Çınar, par. 43. Belirtmek gerekir ki Hasan Güngör başvurusunda ifade olarak "demokratik toplum düzeninde gerekli olma" ifadesi kullanılmaktadır.

92 Hasan Güngör, par. 43, 47; Hasan Güngör (2), par. 38.

93 Hasan Güngör, par. 44.

94 Hasan Güngör (2), par. 47; Zeki Çınar, par. 33.

95 Hasan Güngör (2), par. 39, 42; Zeki Çınar, par. 32. Hasan Güngör başvurusunda ise "toplumsal bir ihtiyaç baskısı"nın demokratik toplum için gerekli olduğuna karar aşamasında atıf yapıldığı görülmektedir. Hasan Güngör, par. 55. Hasan Güngör (2) başvurusunda AYM ilk olarak demokratik toplum düzeninin sağlanması için müdahalenin zorunlu toplumsal ihtiyacı karşılaması gerektiğgini ve istisnai olması gerektiğini belirtmekte ve daha sonra orantılllık şartına yer vermektedir. Bkz. Hasan Güngör (2), par. 39.

96 Hasan Güngör (2), par. 39, 41; Zeki Çınar Başvurusu, par. 32. Hasan Güngör (2) başvurusunda orantıl11ık ayrıca "istenen amaç ile başvurulan sınırlama tedbiri arasında" aşırı dengesizlik olmaması üzerinden tanımlanmaktadır. 
AYM, daha sonra kamu görevlilerinin ifade özgürlüğüne ilişkin değerlendirme yapmaktadır. Hasan Güngör ve Hasan Güngör (2) başvurularında bu değerlendirmeyi genel ilkelerle birlikte ele alan AYM, Zeki Çınar başvurusunda belirtildiği üzere daha sistematik bir inceleme gerçekleştirmektedir. AYM, Hasan Güngör başvurusunda İHAM kararlarına, Hasan Güngör (2) ve Zeki Çınar başvurularında ise Hasan Güngör kararına atıf yapmak suretiyle devletin devlet memurlarının ödev ve sorumluluklarını belirlemede geniş bir takdir marjının bulunduğunu, ${ }^{97}$ devlet memurlarına getirilen sınırlamaların vatandaşlara göre daha fazla olabileceğini ${ }^{98}$ ve devlet memurlarına bağl1lık görevi getirilip memurların ifade özgürlüklerinin sınırlandırılmasının meşru olduğunu 99 belirtmektedir. Fakat, sınırlamanın da bir sınırının olması gerektiğini ifade eden AYM, birey olan devlet memurlarının siyasal ve toplumsal olaylara yönelik ifadeler de dâhil olmak üzere ifade özgürlüğunü haiz olduğunu ortaya koymaktadır; ${ }^{100}$ nitekim ifade özgürlüğünün ortadan kaldırılması demokrasiyi tehlikeye düşürür niteliktedir ${ }^{101}$.

AYM, ifade özgürlüğünü sınırlayan müdahalelerin dar yorumlanması gerektiğini belirtmekte $^{102}$ ve devlet memurlarının ifade özgürlüğünün kapsamını belirlerken kriter olarak isimlendirmemekle birlikte çeşitli değerlendirme kriterlerini ortaya koymaktadır. Hasan Güngör kararında bu kriterler, her ne kadar bu yönde bir ayrıma gidilmese de temel olarak ifadelere ve devlet memuruna ilişkin olmak üzere iki şekilde başlıklandırılabilir. İfadelere yönelik olarak, bu ifadelerin (i) göreve yansıtılıp yansıtılmadığı, (ii) şiddete teşvik içerip içermediği ve (iii) demokratik ilkelerin reddi teşkil edip etmediği değerlendirilirken; devlet memurlarına yönelik olarak, devlet memurlarının (i) hangi görevi yürüttüğü, (ii) görüşlerini dengeli ve siyaseten yansız olarak açıklayıp açıklamadığı, (iii) kişisel tavırlar sergileyip sergilemediği ve (iv) tarafsızlıklarının

\footnotetext{
97 Hasan Güngör, par. 48; Hasan Güngör (2), par. 48; Zeki Çınar, par. 34.

98 Hasan Güngör (2), par. 48.

99 Hasan Güngör, par. 49; Zeki Çınar, par. 35.

100 Hasan Güngör, par. 46, 48-49; Hasan Güngör (2), par. 48, 50-51; Zeki Çınar, par. 34-35.

101 Hasan Güngör, par. 46.

102 Hasan Güngör (2), par. 49; Zeki Çınar, par. 43.
} 
güvence altında olup olmadığg dikkate alınmaktadır ${ }^{103}$. Hasan Güngör (2) başvurusunda bu gibi detaylı kriterlere yer verildiği görülmemekle birlikte, kişinin hangi görevi yürüttüğünün, ifade özgürlüğü kullanılmasının kamu hizmetine yansıtılıp yansıtılmadığının ve tarafsızlığın ihlal edilip edilmediğinin değerlendirildiği ve her olayın kendi özelliklerine göre değerlendirilmesi ve makul gerekçelerin ortaya konması gerektiğinin belirtildiği görülmektedir ${ }^{104}$. Zeki Çınar başvurusunda ise AYM'nin, önceki iki başvurudaki değerlendirmelerini birleştirdiği ve tarafsızlık kavramına ayrıca vurgu yaptığ1 tespit edilmektedir ${ }^{105}$. Zeki Çınar başvurusunda AYM, Hasan Güngör başvurusuyla ortaya konulan kriterlere atıf yapmakta ve ayrıca Hasan Güngör (2) başvurusuna atıf yapmak suretiyle olayın kendi şartları içerisinde değerlendirilmesi ve bir eylemin siyasi parti yararına olduğu kabul ediliyorsa bu hususun makul gerekçeler ile ortaya konulması gerektiğini belirtilmektedir ${ }^{106}$. Bunlara ek olarak, devlet memurlarının ifade özgürlüğüne getirilen sınırlamanın temel amacının "tarafsız davranma" ve "tarafsız görünme" olduğunu belirtmektedir ${ }^{107}$.

AYM'nin ortaya koyduğu kriterlere ilişkin olarak özellikle üç hususun değerlendirilmesi gerekmektedir. İlk olarak, AYM'nin şiddeti teşvik etme gibi hususlara yer verdiği tespit edilebilmektedir. İftira, sövme, suça ve şiddete teşvik ve tahrik gibi ifadelerin ifade özgürlüğünün norm alanına girmeyebileceği ${ }^{108}$ göz önünde tutulduğunda, bu gibi ifadeler kişinin devlet memuru olup olmamasına bakılmaksızın ifade özgürlüğü kapsamında korunmayabilecektir. Fakat düşünce açıklamalarının yapıldığı bağlamın da önemli olduğu düşünüldüğünde ${ }^{109}$ şiddete teşvik eden kişinin devlet memuru olmasının

\footnotetext{
103 Hasan Güngör, par. 46, 48, 50-51; Hasan Güngör (2), par. 50; Zeki Çınar, par. 34-35.

104 Hasan Güngör (2), par. 49-50.

105 Zeki Çınar, par. 40-42.

106 Zeki Çınar, par. 34-35; 43.

107 Zeki Çınar, par.40-42.

108 TANÖR, Bülent / YÜZBAŞIOĞLU, Necmi, 1982 Anayasasına Göre Türk Anayasa Hukuku, 16. Basım, Beta, İstanbul, 2016 s. 177. Ayrıca bkz. TEZCAN / ERDEM / SANCAKDAR vd., 2018, s. 470-472. İfade özgürlüğünün norm alanı dışında kalan görüşler için ayrıca bkz. UYGUN, 2009, s. 2228. Ayrıca bkz. Meki Katar, Başvuru No: 2015/4916, 03.10.2019.

109 Meki Katar, s. 57.
} 
ifade özgürlügünün sınırlandırılması bakımından farklı bir değerlendirmeye yol açıp açmayacağının AYM’nin kararlarında değerlendirilmediği görülmektedir. İkinci olarak, AYM, ifadelerin devlet memurlarının görevlerine yansıtılıp yansıtılmadığı ya da görev sırasında kullanılıp kullanılmadığı değerlendirmesinde bulunsa da AYM'nin devlet memurlarının ifade özgürlüğüne görevleri dışında da sınırlama getirilip getirilemeyeceğine ilişkin açık bir değerlendirme yapmadığı görülmektedir. Örneğin, atıf yapılan Vogt/Almanya kararında İHAM, öğretmenlerin otorite figürü olarak görevlerinin okul dışı aktivitelerine de uzayabileceğini açıkça belirtmektedir ${ }^{110}$. AYM'nin ise, devlet memurlarının ödevlerinin memuriyet görevi dışındaki yaşantılarına da etki göstereceği varsayımında bulunduğu tespit edilebilir. Burada ayrıca belirtmek gerekir ki, devlet memurlarının görevleri dışında bir sınırlamaya tabi olup olmamasındaki belirsizlik, yukarıda belirtildiği üzere, DMK'nin ilgili hükümlerinin belirli ve öngörülebilir olup olmadığı ile de ilişkilendirilebilir. Bir diğer husus, AYM kararlarında tarafsızlık yükümlülüğünün devlet memurlarının ifade özgürlüklerinin korunmasına ilişkin olarak dikkate alınmamış olmasıdır. Atıf yapılan Ahmed vd./Birleşik Krallık kararında, İHAM'ın başvuruya konu sınırlamanın devlet memurlarının da menfaatine olduğu değerlendirilmesi yapıldığı görülmektedir ${ }^{111}$. Bu bağlamda, tarafsızlık yükümlülüğünün bu yönü de karar verilirken değerlendirilebilir konular arasındadır. Bu yükümlülüğün devlet memurunu koruma amacı da göz önünde tutulduğunda, ifade özgürlüğüne getirilen söz konusu sınırlamaların devlet memurunu koruma amacı taşımadığı gerek ölçülülük ilkesi gerek meşru amaç bakımından dikkate alınabilir.

Değerlendirmelerin sonunda AYM, Hasan Güngör başvurusunda, başvurucunun ordu, emniyet gibi alanlara getirilebilecek olan sınırlamalara tabi olmasının gerekmediğini ve başvurucunun görevinde tarafsız davrandığını belirterek ${ }^{112}$ ve verilen cezanın ifade özgürlüğünü engelleyebilecek nitelikte ağır bir ceza olduğu tespitinde

\footnotetext{
110 Vogt/Almanya, par. 60. AYM'nin devlet memurlarının ifade özgürlüklerine ilişkin önemli bir karar olan Vogt/Almanya kararına paralel bir değerlendirme gerçekleştirdiği görülmektedir.

111 Ahmed vd./Birleşik Krallık, par. 63.

112 Hasan Güngör, par. 51.
} 
bulunarak $^{113}$ verilen disiplin cezasının "toplumsal bir ihtiyaç baskısına" karşılık gelmemesi dolayısıyla “demokratik toplumda gerekli olmadığı”na ve Anayasa md. 26'nın ihlal edildiğine oybirliği ile karar vermektedir ${ }^{114}$. Hasan Güngör (2) başvurusunda ise AYM açlık grevi yapılanların ziyaret edilmesinin "kınanabilir" bir eylem olmadığın115 ve eylemin siyasi parti binasında gerçekleştirilmesinin "tek başına" ilgili ve yeterli bir gerekçe olmadığını ${ }^{116}$ belirterek Anayasa md. 26'nın ihlal edildiğine oybirliği ile karar vermektedir $^{117}$. AYM, Zeki Çınar başvurusunda, başvurucunun ifade özgürlüğü ile siyaset yasağının meşru amacı arasında adil bir dengenin gözetilip gözetilmediğinin değerlendirilmesi gerektiğini söyleyerek, ${ }^{118}$ başvurucunun katıldığı toplantıdaki içeriği siyasi partiler aleyhine faaliyet olarak nitelendiren pankarta ilişkin olarak, ifade özgürlüğünün "incitici, şoke edici ya da endişelendirici” ifadeleri de kapsadığın11 ${ }^{19}$ ve başvurucunun mesleki faaliyetini yerine getirirken siyaset yasağına aykırı bir davranış gerçekleştirmediği ve başvurucunun daha kapsamlı özen yükümlülüğünü haiz asker, polis, hâkim ve savcılık gibi meslekleri yürütmediğini belirtmektedir ${ }^{120}$. AYM, pankartın içeriğini ve başvurucunun toplantıya katılmasını ilgili bir gerekçe olarak görmeyerek, mahkemenin ifade özgürlüğü ile siyaset yapma yasağının meşru amacı arasında adil bir denge kurulduğunun ve müdahalenin zorunlu bir toplumsal ihtiyacı karşıladığının gösterilemediği tespiti 1şı̆̆ında ${ }^{121}$ başvurucu hakkında verilen cezanın "zorunlu bir toplumsal ihtiyacı karşılamadığı” ve bu yüzden "demokratik toplum düzeninin gereklerine uygun olmadığı" sonucuna vararak, başvurucunun ifade özgürlügünün ihlal edildiğine oy birliği ile karar vermektedir ${ }^{122}$.

\footnotetext{
113 Hasan Güngör, par. 54.

114 Hasan Güngör, par. 55; Hasan Güngör, Hüküm Kısmı par. B.

115 Hasan Güngör (2), par 51.

116 Hasan Güngör (2), par 52.

117 Hasan Güngör (2), par. 53, Hasan Güngör (2), Hüküm Kısmı par. B, F.

118 Zeki Çınar, par. 44.

119 Zeki Çınar, par. 45.

${ }^{120}$ Zeki Çınar, par. 46.

121 Zeki Çınar, par. 49.

122 Zeki Çınar, par. 48, Zeki Çınar, Hüküm Kısmı par. B, G.
} 
AYM'nin sonuca varırken gerçekleştirdiğgi söz konusu değerlendirmelerine ilişkin ise iki hususun ele alınması gerekmektedir. İlk olarak, AYM'nin orantılılık değerlendirmesinde verilen cezaların ağır olduğu tespitinde bulunduğu; fakat bu ağırlı̆̆ yalnızca ifade özgürlüğü üzerinde yaratılan ağırlık açısından değerlendirdiği görülmektedir. Her ne kadar söz konusu disiplin cezalarının ağır birer ceza olduğu kolay tespit edilebilirse de orantılılık değerlendirmesinin daha detaylı olarak ele alınması bakımından Vogt/Almanya kararı örnek verilebilir. Vogt/Almanya kararında orantılılık değerlendirmesi sırasında devlet memurluğundan ihraç edilmenin kişinin saygınlığı üzerinde olumsuz bir etki yarattığı ve öğretmen olan devlet memurunun geçim kaybına yol açtığ açıkça belirtilmektedir ${ }^{123}$. Devlet memurunun ifade özgürlüğüne yapılacak müdahalenin yaratacağı sonuçların somut olarak ele alınması, orantılılık değerlendirmesi bakımından önem teşkil etmektedir. Ele alınması gereken ikinci husus, AYM'nin, devlet memurlarının görevlerine vurgu yapmasıdır. AYM kararlarında başvurucuların asker, polis, hâkim ve savcılık gibi meslekleri yürütmediği tespit edilebilmektedir. $\mathrm{Bu}$ bağlamda, devlet memurlarının arasında yürüttükleri görev doğrultusunda ifade özgülüklerine müdahale bakımından bir ayrıma gidildiği görülmektedir. $\mathrm{Bu}$ ayrıma gidilmesinin, gerek devlet memurunun tarafsızlık yükümlülüğünün kapsamını belirlemek ve gerekse meşru amaç değerlendirmesi yapmak için gerekli olduğu kabul edilebilir. Vogt/Almanya kararında da benzer şekilde öğretmenlik mesleğinin güvenlik riski taşımadığından bahsedilmektedir ${ }^{124}$. Bu doğrultuda, asker, polis, hâkim ve savcılık mesleğinin "kritik" meslekler olarak ele alınabileceği ve "kritik" görevleri ifa eden devlet memurlarının ifade özgürlüklerinin daha fazla sınırlandırılabileceğini kabul ettiği anlaşılmaktadır. Fakat "kritik" görevlerin ne olduğunun mutlak bir şekilde tespitinin yapılması mümkün gözükmemektedir. Her ne kadar İHAM öğretmenlik mesleğinin güvenlik riski taşımadığını söylese ve AYM yalnızca asker, polis, hâkim ve savcılık mesleğine atıf yapmış olsa da belirli durumlarda özellikli konumu olan öğretmenlik

\footnotetext{
123 Vogt/Almanya, par. 60. Otto/Almanya kararında ise devlet memurunun terfi almamasının geçim kaybına yol açmayacağı belirtilmektedir. Karş. Otto/Almanya.

124 Vogt/Almanya, par. 60.
} 
mesleğinin de "kritik" olabileceği söylenebilir ${ }^{125}$. Örneğin ilkokul öğretmeninin ders esnasında kendi görüşlerini empoze etmeye çalışmasının ${ }^{126}$. bir askerin kendi görüşlerini açıklamasından daha büyük bir etkiye yol açması mümkündür. Bu doğrultuda "kritik" mesleklerin kategorik olarak ele alınması yerine olay özelinde o mesleğin "kritik" olup olmadığı değerlendirilmesi yerinde olacaktır. Ayrıca belirtmek gerekir ki, bir mesleğin "kritik" konumda olması, her müdahalenin meşru ve demokratik toplum gereklerine uygun kabul edileceği yorumuna yol açmamalıdır. Aksi durumda, kritik meslekleri yürüten kişilerin temel hak ve hürriyetlerinin hukuka aykırı bir şekilde sınırlandırılması söz konusu olacaktır ${ }^{127}$. Bu noktada, incelenen AYM kararlarında atıf yapılmamakla birlikte kilit dava ("key case”) Baka/Macaristan kararına değinilebilir"128. İHAM, yarg1 reformunu eleştiren hâkimin, ${ }^{129}$ yargı tarafsızlığının korunması amacıyla görev süresinin erken sonlandırılmasına (“premature termination”) ilişkin olayda, ifade özgürlüğüne yapılan müdahalenin ileri sürülen meşru amaç ile bağdaşmadığın1 ${ }^{130}$ ve demokratik toplumda gerekli olmadığını belirterek İHAS Md. 10’un ihlal edildiği kararına

125 Öğretmenlik mesleğinin özellikli bir konumu olmasına ilişkin bkz. Z.A. Başvurusu, B. No: 2013/2928, 18.10.2017, par. 70 .

126 Öğretmenlerin ifade özgürlüğünün sınırlandırılması değerlendirilmesi için bkz. SEVER, 2020, s. 11791180.

127 Örneğin, Z.A. Başvurusuna konu olayda bir öğretmenin cinsel yönelimi sebebiyle meslekten çıkarılması ve mesleğe dönme isteminin kabul edilmemesi söz konusudur. Bu kararda AYM, eşitlik ilkesinin ve özel hayata saygı hakkının ihlal edilmediğine karar vermiştir. Bkz. Z.A. Başvurusu, Hüküm Kısmı par. D. AYM, kişinin meslekten çıkarılmasının ve mesleğe dönme isteğinin reddedilmesinin gerekçesinin cinsel yönelim olmadığını ve fakat görev yaptığı okulda yansıttığı davranışları olduğunu belirtmektedir. Bkz. Z.A. Başvurusu, par. 73-76. Bununla birlikte, karşıyda bu davranışların doğruluğunun ispatlanamadığı ve kişinin meslekten çıkarılmasının ve mesleğe dönme talebinin reddedilmesinin cinsel yönelimi ile bağlantılı olduğu ortaya konmaktadır. Bkz. Z.A. Başvurusu, Engin Yıldırım'ın Karşıyu, özellikle par. 21-23, 39-41. Öğretmenin cinsel yöneliminin öğretmenlik mesleği ile ilgisi olmamasına ve mesleki faaliyetin aksatıldığının tespit edilememesine rağmen AYM'nin ihlal olmadığına karar vermesi özellikli bir meslek yürüten kişinin temel hak ve hürriyetlerinin hukuka aykırı bir şekilde sınırlanmasına örnek teşkil etmektedir.

128 Baka/Macaristan [BD], Başvuru No: 20261/12, 23.06.2016. Baka/Macaristan kararının kritik dava olarak listelenmesine ilişkin bkz. European Court of Human Rights Key Cases 2016, https://www.echr.coe.int/Documents/Cases_list_2016_ENG.pdf, (erişim tarihi: 10.04.2020).

129 Olaylar için bkz. Baka/Macaristan, par. 11-37.

${ }^{130}$ Baka/Macaristan, par. 156. 
varmaktadır ${ }^{131}$. Bu doğrultuda, "kritik” görevlerde bulunan devlet memurlarının ifade özgürlüğüne yapılan müdahaleler değerlendirilirken yalnızca görevin kritik olup olmaması değil, devlet memurlarının tarafsız davranmamasının bu görevin sağlamış olduğu konum ve/veya ilişski sebebiyle yaratacağı etki dikkate alınmalıdır. Bu bağlamda kritik görevlerde bulunan devlet memurlarının ifade özgürlüğüne yapılan müdahalenin de Anayasaya aykırı olabileceği göz önünde bulundurulmalıdır.

AYM kararlarına ilişkin ayrıca değerlendirilmesi gereken husus, kararlarda her ne kadar ifade özgürlügünden tamamen mahrum bırakılmanın mümkün olmadığı belirtilse $\mathrm{de}^{132}$ siyasi ifade özgürlüklerinin tamamen sınırlanmasının hakkın özüne dokunma teşkil edip etmediği yönünde bir değerlendirme yapılmamasıdır. AYM'nin atıf yaptığı Ahmed vd./Birleşik Krallık kararında sınırlamanın tüm siyasi ifadelere yönelik olup olmadığının değerlendirildiği görülmektedir ${ }^{133}$. İfade özgürlüğünün özüne dokunulmuş sayılması için tüm düşüncelerin yasaklanmış olması gerekmemektedir; siyasi düşünce yönünden sınırlandırılmış olması da öze dokunan bir sınırlama teşkil edebilir ${ }^{134}$. Öze dokunma yasağı ile birlikte, temel hak ve özgürlüğün varlık nedeninin ortadan kalkmasına engel olunmaya çalışıldığı ${ }^{135}$ göz önünde tutulduğunda, AYM'nin devlet memurlarının siyasi ifade özgürlüğünün tamamen ortadan kaldırılmasının hakkın özüne dokunma teşkil edebileceği değerlendirmesini ayrıca yapması beklenebilir. Hakkın özü değerlendirmesine ek olarak, AYM'nin devlet memurlarının ifade özgürlüklerinin tamamen ortadan kaldırılmasını Anayasa md. 14 kapsamında ele alması da mümkündür. Nitekim, bu gibi bir sınırlama Anayasa md. 14/2 ile öngörülen “Anayasayla tanınan temel hak ve hürriyetlerin yok edilmesi” anlamını taşıyabilecektir.

${ }^{131}$ Baka/Macaristan, par. 175-176.Ayrıca bkz. Kayasu/Türkiye ve Albayrak/Türkiye, Başvuru No: 38406/97, 31.01.2008.

${ }^{132}$ Hasan Güngör, par. 51; Hasan Güngör (2), par. 50. Hasan Güngör başvurusunda AYM öz değerlendirmesi yapılması gerektiğini söylemekle birlikte siyasi ifade özgürlüğü bakımından bu değerlendirmeyi gerçekleştirmemektedir. Bkz. Hasan Güngör, par. 50.

133 Ahmed vd./Birleşik Krallık, par. 63.

134 TANÖR, 1969, s. 178-179.

135 SAĞLAM, Fazıl, Temel Hakların Sınırlanması ve Özü, Ankara Üniversitesi Siyasal Bilgiler Fakültesi Yayınları No: 506, Ankara, 1982, s. 155-156. 
AYM kararlarına ilişkin ele alınabilecek olan diğer husus, devlet memurlarının açıklamalarında kamu yararı bulunması hususudur. Bu çalışma kapsamında incelenen başvurulara konu olan olaylar bakımından devlet memurlarının ifadelerinin kamuyu ilgilendiren konularda olduğu ve bu ifadelerin açıklanmasında kamu yararı bulunduğu özel olarak söylenemeyecek olsa da, ${ }^{136}$ devlet memurlarının ifade özgürlüklerine getirilen sınırlamalar değerlendirilirken ifadelerin içeriğinin ne olduğu ve devlet memurlarının haber uçuran konumunda olması durumu da değerlendirilebilir ${ }^{137}$. Nitekim İHAM da önemli kamu yararı ("strong public interest”) teşkil eden açıklamaların korunabileceğini belirtmektedir ${ }^{138}$. Bu doğrultuda devlet memurlarının açıklamalarının içeriğinin değerlendirmesi ve bu açıklamalarda kamu yararı bulunup bulunmadığının ele alınması da devlet memurlarının ifade özgürlüklerine getirilen sınırlamalar bakımından özellikle söz konusu sınırlamanın demokratik toplumda gerekli olup olmadiğının değerlendirilmesi bakımından önem teşkil edecektir.

\section{ANAYASA MAHKEMESI KARARLARI IŞIĞINDA DEVLET MEMURLARININ IFADE ÖZGÜRLÜĞÜNÜN DEĞERLENDİRÍLMESI}

Siyasi konulara ilişkin ifade özgürlügünün korunmasının demokratik toplumlar bakımından özel önem teşkil ettiğ $1^{139}$ ve ifade özgürlüğünün sağlandığının kabul edilmesi için herkesin bu özgürlükten yararlanmasına imkân verilmesi gerektiği ${ }^{140}$ göz önünde tutulduğunda, devlet memurlarının ifade özgürlüğüne ilişkin olarak DMK hükümlerinin nasıl yorumlanması gerektiği AYM kararları 1şığında ele alınmalıdır. İfade edildiği üzere,

\footnotetext{
${ }^{136} \mathrm{Bu}$ değerlendirmemiz söz konusu ifadelerin kamuyu hiç ilgilendirmemesi veya açıklama yapılmasında herhangi bir kamu yararı bulunmaması tespiti değildir; nitekim kamusal tartışmaya katkı sağlayabilecek olan her ifadenin açıklanmasında kamu yararı bulunacaktır. Burada belirtilmek istenen husus bu ifadelerin kamu yararının sağlanması açısından "özel” bir önem taşımamasıdır.

137 Kamu görevlilerinin haber uçuran konumunda olmasına ilişkin detaylı değerlendirme için bkz. SEVER, 2020, s. 1188-1192.

138 Guja/Moldova [BD], Başvuru No: 14277/04, 12.02.2008, par. 72. İHAM bu korunmanın sağlanmasını belirli koşullara bağlamıştır. Koşullar için ayrıca bkz. Guja/Moldova, par. 80-96.

139 TEZCAN / ERDEM / SANCAKDAR vd., 2018, s. 457. İHAS kapsamında siyasal konulara ilişkin ifade özgürlüğünün “yüksek derecede” korunmasına ilişkin bkz. Uygun, s. 45. İHAM'ın ve AYM'nin atfettiği özel öneme ilişkin bkz. KARAN, 2018, s. 8, 10.

140 SUNAY, 2001, s. 2.
} 
devlet memurlarının ifade özgürlüğü doktrinde tarafsızlık, sadakat ve bağlılık yükümleri ile ilişkili olarak ele alınmaktadır. AYM, devlet memurlarına bağlılık görevi getirilmesinin meşru olduğunu belirtmektedir; fakat değerlendirmelerini bu yükümlülük ile ilişkili olarak gerçekleştirmemektedir. Devlet memurlarının sadakat ve bağlılık yükümlülüğüne ilişkin açıklamalar dikkate alındığında, devlet memurlarının ifade özgürlüğünün "sadakat” ve "bağlılık” gibi soyut kavramların geniş yorumlanması sebebiyle sınırlanması mümkün olmamalıdır. $\mathrm{Bu}$ doğrultuda $\mathrm{DMK}$ hükümlerinin yorumlanmasında temel olarak tarafsızlık yükümlülügüünun ele alınması gerekmektedir.

AYM kararları devlet memurlarının ifade özgürlüklerini değerlendirirken yukarıda tespit ettiğimiz birçok farklı kriteri ortaya koymakta ise de ifadelere ve devlet memurlarına yönelik olarak ortaya konan bu kriterlerin temelinde "tarafsız davranma" ve "tarafsız görünme" olduğu görülmektedir. Bu doğrultuda devlet memurlarının ifade özgürlüğü değerlendirmesi (i) devletin tarafsızlığına olan güvene zarar verilip verilmediği ve (ii) devlet memurlarının faaliyeti yerine getirirken tarafsız davranıp davranmadığı başlıklarında objektif olarak ele alınmalıdır. Görevi dışında bir devlet memurunun siyasi ifade özgürlüğünü kullanması doğrudan devletin tarafsızlığına olan güvenin sarsılması için yeterli olmamalıdır; fakat bu özgürlüğün kullanılması vatandaşların devletten hizmet alamayacağını düşünmelerine yol açarak hizmet talebinde bulunmalarına engel teşkil eder nitelikte ise ifade özgürlügünün sınırlandırılması kabul edilebilir. Devlet memurunun görevi sırasında, yani faaliyeti yerine getirirken tarafsız davranıp davranmadığ ise, devlet memurunun veya hizmet talep edenin görüşü ne olursa olsun faaliyetin sunulup sunulmadığının tespitine ilişkindir. Bu açıklamalar doğrultusunda (i) vatandaşların hizmetten yararlanacakları yönündeki güveninin engellenmemesi veya (ii) hizmetin gereği gibi yerine getirilmesi koşuluyla devlet memurlarının siyasi ifade özgürlüklerinin korunması gerektiği sonucuna ulaşılmalıdır.

DMK hükümlerinin lafzına bakıldığında, devlet memurlarının hiçbir bir şekilde siyasi içerikli ifadede bulunamayacakları belirtilebilir. DMK'nin herhangi bir istisna tanımadan siyasi ifade özgürlügü kullanımını tamamen yasaklaması Anayasa ile bağdaşır nitelikte değildir ve yukarıda varılan sonuca ulaşmayı engellemektedir. Bu çerçevede DMK'nin ilgili maddelerinde değişikliğe gidilmesi gerektiği söylenebilir. Bu değişiklik 
devlet memurlarının yerine getiremeyeceği çeşitli faaliyetlerin sayılması; fakat siyasi konularda görüş bildirebileceklerinin açıkça kabulü şeklinde olabilir. Örneğin, Amerika Birleşik Devletleri hukukunda, Hatch Kanununda (The Hatch Act) devlet memurlarının yapması yasak olan siyasi faaliyetler detaylı olarak listelenmekle birlikte, devlet memurlarının siyasi konularda görüş bildireceği açıkça güvence altına alınmaktadır ${ }^{141}$. Bir diğer değişiklik ise, yasaklama içeren hükümlerin korunması yerine devlet memurlarının siyasi faaliyetlerde bulunurken uyması gereken kuralların yazılması şeklinde gerçekleştirilebilir ${ }^{142}$. Örneğin Alman hukukunda, ${ }^{143}$ Alman Devlet Memurları Kanunu (Bundesbeamtengesetz) md. 60 uyarınca "memurlar, siyasi faaliyette bulunurken, toplumun geneli karşısındaki konumlarının ve görevlerinin gerektirdiği, 1lımlılığı ve sinırlamayı sağlamalılardır" ${ }^{\prime 44}$. Belirtmek gerekir ki, tarafsızlık yükümlülüğünün devlet memurlarının düşünce ve kanaat özgürlüklerini koruyan yönü düşünüldüğünde, Amerika Birleşik Devletleri örneğinin tercih edilmesi bu amacin sağlanması bakımından daha uygun olacaktır.

1415 U.S.C. $\$ 7323$ (c). Amerika Birleşik Devletleri hukukunda devlet memurlarının yapabilecekleri veya yapamayacakları siyasi faaliyetlere ilişkin olarak bkz. 5 U.S.C. § $7323-7325$. İlgili kanun hükümleri için Cornell Law School internet adresinden yararlanılmıştır. Bkz. Legal Information Institute, Cornell Law School, https://www.law.cornell.edu/uscode/text , (erişim tarihi: 10.04.2020). Ayrıca genel bilgi için bkz. US Office of Special Counsel, Federal Employee Hatch Act Information, https://osc.gov/Services/Pages/HatchAct-Federal.aspx\#tabGroup13/tabGroup51 ， (erişim tarihi: 10.04.2020).

${ }^{142}$ Belirtmek gerekir ki, bu çalışma yabancı hukuklarla bir karşılaştırma yapmayı hedeflememekte, yalnızca örnek teşkil etmesi bakımından Amerika Birleşik Devletleri ve Alman mevzuatına atıf yapmaktadır.

${ }^{143}$ Alman hukuku için bkz. BATTIS, Ulrich, "Civil Servants and Politics in Germany", Civil Servants and Politics, (der. C. Neuhold, vd.), Londra, 2013 (s. 152-169), s. 152-169.

${ }^{144}$ Metin İngilizce tercümesinden çevrilmiştir. İngilizce tercümesi için bkz. BATTIS, 2013, s. 165. İlgili maddenin Almanca metni şu şekildedir: "(2) Beamtinnen und Beamte haben bei politischer Betätigung diejenige Mäßigung und Zurückhaltung zu wahren, die sich aus ihrer Stellung gegenüber der Allgemeinheit und aus der Rücksicht auf die Pflichten ihres Amtes ergeben.”. Bkz. Bundesministerium der Justiz und für Verbraucherschutz, https://www.gesetze-iminternet.de/bbg_2009/ 60.html, (erişim tarihi 10.04.2020). Alman hukukunda hakimlerin herhangi bir vatandaş gibi siyasi görüşlerini ifade edebilmesine iliş̧kin ayrıca bkz. Venice Comission, Report On the Freedom of Expression of Judges, Venedik 19-20 Haziran 2015, https://www.venice.coe.int/webforms/documents/default.aspx?pdffile $=\mathrm{CDL}-\mathrm{AD}(2015) 018$-e , (erişim tarihi: 10.04.2020), par. 47. 
DMK'nin ilgili hükümlerinin teleolojik yorum çerçevesinde ${ }^{145}$ değerlendirilmesi de mümkündür. DMK'de ifade özgürlügüün sınırlayan normların amacının devlet memurlarının tarafsızlıkları sağlanarak vatandaşların kamu hizmetinden yararlanmalarının engellenmemesi olduğu düşünüldüğünde, DMK md. 7 vatandaşların hizmetten yararlanacakları yönündeki güvenlerine zarar verilmesine yol açacak veya kamu hizmetinin gereği gibi yerine getirilmesine engel olacak şekilde "herhangi bir siyasi parti, kişi veya zümrenin yararını veya zararını hedef tutan bir davranışta bulunma" ve "siyasi ve ideolojik amaçlı beyanda ve eylemde bulunma ve bu eylemlere katılma" yasağı olarak kabul edilmelidir.

AYM kararları açısından önem taşıyan DMK md. 125 (D) (o) ise benzer şekilde vatandaşların hizmetten yararlanacakları yönündeki güvenlerine zarar verilmesine yol açacak veya kamu hizmetinin gereği gibi yerine getirilmesine engel olacak şekilde "herhangi bir siyasi parti yararına veya zararına fiilen faaliyette bulunma" yasağı olarak kabul edilebilir. Görüldüğü üzere, mevcut DMK hükümlerini, AYM bireysel başvuru kararları 1şığında ifade özgürlüğüne müdahaleye gerek kalmayacak şekilde yorumlamak mümkündür. $\mathrm{Bu}$ doğrultuda, Anayasaya uygun yorum çerçevesinde, ${ }^{146}$ DMK'de bir değişikliğe gidilmeden de devlet memurlarının siyasi ifade özgürlüklerini her kullanmalarının DMK hükümlerine aykırılık teşkil etmeyeceği yorumu yapılabilir ${ }^{147}$.

\section{SONUÇ}

AYM, Hasan Güngör, Hasan Güngör (2) ve Zeki Çınar kararlarında devlet memurluğu statüsünün ifade özgürlüğünün sınırlanmasına yol açabileceğini kabul etmekle birlikte, bu statünün devlet memurlarının ifade özgürlüğünü kullanmasını engellemek için her durumda tek başına yeterli olmadığını belirtmektedir. Temel hak ve özgürlükler rejimi açısından önem taşıyan bu yaklaşımın AYM tarafından her daim

\footnotetext{
145 Teleolojik yorum ile normun "nesnel amacının" tespit edilmesi ve ona uygun yorum yapılması ifade edilmektedir. Nesnel-teleolojik yoruma ilişkin bkz. ODER, Bertil Emrah, Anayasa Yargısında Yorum Yöntemleri, Beta, İstanbul, 2010, s. 103-110.

146 Anayasaya uygun yorumun koşulları farklı yorum yöntemleri sonucunda ortaya çıkan sonuçların en az birinin diğerleri ile çelişen bir yorum içermesi ve bu yorumlardan en az bir yorumun Anayasaya uygun olmasidır. ODER, 2010, s. 151.

147 Danıştay içtihadında Anayasaya uygun yorumun kullanılmasına ilişkin bkz. ODER, 2010, s. 144-149.
} 
sürdürülüp sürdürülmeyeceğinin takipçisi olunması gerekmektedir. İncelenen kararlardan devlet memurlarının hükümetteki siyasi partiyi ya da parti liderlerini doğrudan eleştirmesi ya da övmesi, yasadışı oluşumların fikirlerini destekleyici beyanlarda bulunması, fikirlerini görev sırasında açıklaması, kritik görevleri ifa etmeleri ya da haber uçuran konumunda olmaları durumunda AYM'nin nasıl yaklaşım sergileyeceği kesin olarak tespit edilememektedir. İncelenmiş olan kararlar doğrultusunda AYM'den kendi ortaya koyduğu kriterler çerçevesinde devlet memurlarının ifade özgürlüklerine ilişkin tarafsızlık yükümlülüğü temelinde bir değerlendirme yapması ve vatandaşların hizmetten yararlanmasına engel olunmadığı sürece özgürlükçü bir yaklaşımı benimsemesi beklenebilir. Bu değerlendirmeler gerçekleştirilirken, tarafsızlık yükümlülüğünün devlet memurlarını koruyan boyutu olduğunun da unutulmaması gerekmektedir. AYM'nin kararlarında mevcut olduğu düşünülen özgürlükçü yaklaşımın DMK hükümlerinin ifade özgürlüğü bakımından yorumlanmasında idarelere ve çeşitli içtihatlarında sergilediği özgürlük odaklı yaklaşımını her kararında sürdürmesi bakımından Danıştay’a 1şık tutması umut edilmektedir. 


\section{KAYNAKÇA}

AKILLIOĞLU, Tekin, "Düşünce ve Anlatım Özgürlüğü ve Kamu Görevlileri”, İnsan Hakları ve Kamu Görevlileri, (Yayına Hazırlayan: M. Gülmez), Türkiye ve Orta Doğu Amme İdaresi Enstitüsü, Ankara, 1992, (s. 25-34).

AKYILMAZ, Bahtiyar, “Türk Hukukunda Kamu Görevlilerinin Devlete Sadakat Yükümlülüğü”,

Danıştay ve İdari Yargı Günü 149. Yıl Sempozyumu, Danıştay Yayınları No: 93, Ankara, May1s 2017, (s. 15-34).

BATTIS, Ulrich, "Civil Servants and Politics in Germany", Civil Servants and Politics, (der. C. Neuhold, vd.), Londra, 2013 (s. 152-169).

Bundesministerium der Justiz und für Verbraucherschutz, https://www.gesetze-iminternet.de/bbg_2009/_60.html, (erişim tarihi 10.04.2020).

ÇİTÇİ, Oya, "Siyasal Haklar ve Kamu Görevlileri”, İnsan Hakları ve Kamu Görevlileri, (Yayına Hazırlayan: Mesut Gülmez), Türkiye ve Orta Doğu Amme İdaresi Enstitüsü, Ankara, 1992, (s. 89-110).

DURAN, Lütfi, İdare Hukuku Ders Notları, İstanbul Üniversitesi Yayınları, Fakülteler Matbaası, İstanbul, 1982.

ERSÖZ, A. Kürşat, "Devlet Memurlarının Siyaset Yapma Yasağı ve Değerlendirilmesi”, Türkiye Adalet Akademisi Dergisi, Y1l: Nisan 2016, Say1: 26, (s. 71-104).

European Court of Human Rights Key Cases 2016, https://www.echr.coe.int/Documents/Cases list 2016_ENG.pdf ， (erişim tarihi: 10.04.2020)

GİRITLİ, İsmet, "Devlet Memurları Kanunu Tasarısı ve Bazı Eksiklikleri”, İstanbul Üniversitesi Hukuk Fakültesi Mecmuası, Cilt: 30, Sayı: 1-2, (s. 3-12).

GÖZLER, Kemal, İdare Hukuku, Cilt: 2, Güncellenmiş 3. Bas1, Ekin Kitabevi Yayınları, Bursa, 2019.

GÖZÜBÜYÜK, Şeref / TAN, Turgut, İdare Hukuku Genel Esaslar I, 11. Basım, Turhan Kitabevi, Ankara, 2016. 
GÜRAN, Sait, İfade Hürriyeti Üzerine İdare’nin Yetkileri, İstanbul Üniversitesi Yayınları No: 1337, Cezaevi Matbaası, İstanbul, 1969.

GÜRAN, Sait, Memur Hukukunda Kayırma ve Liyakat Sistemi, Fakülteler Matbaası, İstanbul, 1980.

GÜRİZ, Adnan, “İfade Hürriyetinin Sınırları”, Düşünce Özgürlüğü, (Hazırlayan: H. Ökçesiz), Afa Yayınları, İstanbul, 1998, (s. 82-86).

GÜVEN, H. Sami, “İdare Siyaset İlişkileri ve Personel Yönetimi Açısından Önemi”, Amme İdaresi Dergisi, Y11: 1976, Cilt: 9, Say1: 1, (s. 50-70).

İNCEOĞLU, Sibel, "Hak ve Özgürlükleri Sınırlama ve Güvence Rejimi”, İnsan Hakları Avrupa Sözleşmesi ve Anayasa: Anayasa Mahkemesine Bireysel Başvuru Kapsamında Bir İnceleme, (der. S. İnceoğlu), 3. Basım, Beta, İstanbul, Ekim 2013, (s. 23-52).

KABOĞLU, İbrahim, “Düşünce Özgürlüğü”, İnsan Hakları, (der. K. Tankuter), Yap1 Kredi Yayınları, İstanbul, 2000, (s. 106-120).

KABOĞLU, İbrahim, Özgürlükler Hukuku, Afa Yayınları, İstanbul, 1993.

KAMAN KARAN, Nur, Devlet Memurluğunun Sona Ermesi, Seçkin Yayıncılık, Ankara, 2003.

KARAN, Ulaş, “İfade Özgürlüğü Hakkı”, İnsan Hakları Avrupa Sözleşmesi ve Anayasa: Anayasa Mahkemesine Bireysel Başvuru Kapsamında Bir İnceleme, (der. S. İnceoğlu), 3. Bas1, Beta, İstanbul Ekim 2013, (s. 355-379).

KARAN, Ulaş, İfade Özgürlüğü Anayasa Mahkemesine Bireysel Başvuru Eı Kitapları Serisi 2, Avrupa Konseyi Ankara Program Ofisi, Ankara, Nisan 2018.

Legal Information Institute, Cornell Law School, https://www.law.cornell.edu/uscode/text, (erişim tarihi: 10.04.2020).

ODER, Bertil Emrah, Anayasa Yargısında Yorum Yöntemleri, Beta, İstanbul, 2010. 
ODER, Burak, "Regülasyon Kavramı Üzerine Bir Deneme”, Ali Ülkü Azrak 75. Yaş Armağanı, İstanbul, Kasım 2008.

OKAY TEKİNSOY, Özge, İdare Hukukunda Kamu Düzeni Kavramı, On İki Levha Yayıncılık, İstanbul, Mart 2011.

ONAR, Sıddık Sami, İdare Hukukunun Umumi Esasları, Cilt: 2, 3. Basım, İsmail Akgün Matbaas1, İstanbul, 1966.

SAĞLAM, Fazıl, Temel Hakların Sınırlanması ve Özü, Ankara Üniversitesi Siyasal Bilgiler Fakültesi Yayınları No: 506, Ankara, 1982.

SANCAKDAR, Oğuz, Disiplin Yaptırımı Olarak Devlet Memuriyetinden Çıkarma ve Yargısal Denetim, Yetkin Yayınları, Ankara, 2001.

SELÇUK, Sami, "Düşün Özgürlüğü,” Düşünce Özgürlüğü, (Hazırlayan: H. Ökçesiz), Afa Yayınları, İstanbul, 1998, (s. 293-314).

SEVER, Dilşad Çiğdem, "Kamu Görevlilerinin İfade Özgürlüğü ve Disiplin Hukukunun Sınırı”, Prof. Dr. Metin Günday Armağanı, Cilt: 2, Atılım Üniversitesi, Ankara, 2020, (s. 11651211).

SUNAY, Reyhan, Avrupa Sözleşmesinde ve Türk Anayasasında İfade Hürriyetini Muhtevası ve Sinırları, Liberal Düşünce Topluluğu, Ankara, 2001.

ŞİRIN, Tolga, Anayasa Mahkemesi Kararları Işı̆̆ında Bireysel Başvuru Hakkı, On İki Levha Yayıncılık, İstanbul, Ekim 2015.

TANÖR, Bülent, "Temel Hak ve Özgürlüklerin Genel Rejimi”, İnsan Hakları, (der. K. Tankuter), Yapı Kredi Yayınları, İstanbul, 2000, (s. 47-56).

TANÖR, Bülent, Siyasi Düşünce Hürriyeti ve 1961 Türk Anayasası, Öncü Kitapevi, İstanbul, 1969.

TANÖR, Bülent / YÜZBAŞIOĞLU, Necmi, 1982 Anayasasına Göre Türk Anayasa Hukuku, 16. Basım, Beta, İstanbul, 2016. 
TEZCAN, Durmuş / ERDEM, Mustafa Ruhan / SANCAKDAR, Oğuz, vd., İnsan Hakları El Kitabı, Güncellenmiş 7. Basım, Seçkin Yayıncılık, Ankara, Eylül 2018.

TEZİÇ, Erdoğan, “Türkiye'de Siyasal Düşünce ve Örgütlenme Özgürlüğü”, Anayasa Yargısı Dergisi, Y1l: 1990, Cilt: 7, (s. 31-46).

TUTUM, Cahit, "Memurluk Statüsü”, Amme İdaresi Dergisi, Cilt: 5, Sayı: 2 Haziran, (s. 3-10).

ULUSOY, Ali D., Yeni Türk İdare Hukuku, Yetkin Yayınları, Ankara, 2019.

US Office of Special Counsel, Federal Employee Hatch Act Information, https://osc.gov/Services/Pages/HatchAct-Federal.aspx\#tabGroup13|tabGroup51 , (erişim tarihi: 10.04.2020).

UYGUN, Oktay, “Avrupa İnsan Hakları Sözleşmesi ve Türk Hukukunda İfade Özgürlüğünün Sınırlanması", Türkiye'de İfade Özgürlüğü, (der. T. Koçak, vd.), BGST Yayınları, İstanbul, 2009, (s. 15-67).

Venice Comission, Report On the Freedom of Expression of Judges, Venedik 19-20 Haziran 2015, https://www.venice.coe.int/webforms/documents/default.aspx?pdffile=CDL$\underline{\operatorname{AD}(2015) 018-e}$, (erişim tarihi: 10.04.2020).

YAYLA, Yıldızhan, İdare Hukuku, 2. Basım, Beta, İstanbul, 2010. 